\title{
SOLUTIONS TO THE INTRACTABILITY OF DISTRIBUTIONAL CONCERNS
}

\author{
Nicholas L. Georgakopoulos*
}

\begin{abstract}
Law and Economics has been attacked for ignoring distributional concerns, despite that utilitarianism has strong redistributional implications. Recently, the disregard of some scholars to distribution has been defended with the claim that only the tax system aught to provide redistribution. This essay challenges both claims. The utilitarian foundation of Law and Economics does argue for redistribution. Moreover, the wastefulness of redistributional rules is a truism, rather than an objection. Redistributional rules cannot be rejected against the current suboptimal income tax, because even if they wastefully deter work, the current tax may deter work more. Redistributional rules can even be superior to optimal income taxation. Redistributional rules can be superior because they can redistribute welfare, rather than money, avoiding any tax disincentive; because they can induce the revelation of skill and avoid the distortions of even an optimal income tax; because they can improve the incentives of even an optimal tax by burdening leisure activities and reducing the taxes' deterrence of work; and because they may produce distortions that are synergistic with the redistributional goal.

Several potentially advantageous redistributive rules are identified, such as the right to abortion, emissions trading, bottle laws, the homeownership bias, public housing, and excessive tort liability from accidents in leisure activities. Their superiority to an equivalently redistributive, optimal, tax substitute is shown. Law and Economic scholarship is uniquely poised to design such rules, as several existing proposals show, such as the proposal for "blind" political contributions, for random Lojack installations in high-crime appliances, or for "shall-issue" firearm permits. Further proposals are discussed: intellectual property fees, redistributive Coasean bargains, missed pre-natal care vouchers, and school licenses for standardized scores.
\end{abstract}

* Professor of Law, Indiana University School of Law-Indianapolis; academic website: www.nicholasgeorgakopoulos.org. I wish to thank Justice Ted Boehm, Daniel Cole, Kenny Crews, Peter Grossman, Christine Jolls, Andy Klein, Robert Lawless, Tom Miceli, Eric Posner, Eric Rasmusen, Pierre Schlag, Stewart Schwab, Steve Shavell, Peter Siegelman, Jeff Stake, George Wright and Stephen Utz for their helpful comments. I wish to acknowledge the generous financial support of the Indiana University School of Law-Indianapolis and the patient cooperation of the Rutgers Law Journal. 


\section{ISSUES OF DISTRIBUTION}

Social welfare cannot be separated from questions of distribution. Economic analysis, however, has been sharply criticized for ignoring distributional issues. ${ }^{1}$ This accusation is not meritless, ${ }^{2}$ although it is outdated. ${ }^{3}$ Scores of research articles in Law and Economics ignore the consequences of their analysis for distribution. This tendency is driven

1. A thorough discussion of the premises of law and economics and the use of the theories of Coase to avoid concerns with the distribution of wealth, along with an attempt to reclaim Coase for the Left is in Pierre Schlag, An Appreciative Comment On Coase's The Problem Of Social Cost: A View From The Lefi, 1986 WIS. L. REV. 919. The point that law and economics ignores distributional concerns is widely observed, id., passim (collecting citations). See also Jules L. Coleman, Efficiency, Utility, and Wealth Maximization, 8 HoFstra L. REV. 509 (1980). The explanation for why economic analysis of law ignores the distributive effects relies on the power of the state to redistribute wealth. See A. MrTCHELL POLINSKY, AN INTRODUCTION TO LAW AND ECONOMICS 7-10 (2d ed. 1989).

2. Two of the leading figures in law and economics, Professors Louis Kaplow and Steven Shavell of Harvard Law School, explicitly defend the position that distributional concerns should be delegated to tax analysis. See Louis Kaplow \& Steven Shavell, Should Legal Rules Favor the Poor? Clarifying the Role of Legal Rules and the Income Tax in Redistributing Income, 29 J. LEGAL STUD. 821 (2000) [hereinafter Clarifying]; Louis Kaplow \& Steven Shavell, Why the Legal System Is Less Efficient than the Income Tax in Redistributing Income, 23 J. LEGAL STUD. 667 (1994) [hereinafter Redistributing]; Steven Shavell, A Note of Efficiency vs. Distributional Equity in Legal Rulemaking: Should Distributional Equity Matter Given Optimal Income Taxation?, 71 AM. ECON. REv. 414 (1981). They also argue that the law should not pursue goals other than increasing welfare. Louis Kaplow \& Steven Shavell, Fairness Versus Welfare, 114 HARV. L. REV. 961 (2001); Louis Kaplow \& Steven Shavell, Notions of Fairness Versus the Pareto Principle: On the Role of Logical Consistency, 110 YALE L.J. 237 (2000). Their thesis, however, allows (and requires) the pursuit of redistribution if, and only if, it increases aggregate welfare, which is consistent with the analysis of this article.

3. Several members of the younger generation of law and economics scholars-who entered legal academia since, roughly, 1990-have explicitly taken the opposite position, and have defended the pursuit of redistributive goals with non-tax nules. See, e.g., Mathew D. Adler \& Eric A. Posner, Re-thinking Cost-Benefit Analysis, 109 YALE L.J. 165, 204-09 (1999) (arguing that utility can be compared between persons, which leads to a validity of distributional concerns); Christine Jolls, Behavioral Economic Analysis of Redistributive Legal Rules, 51 VAND. L. REv. 1653, 1656 (1998) [herinafter Behavioral Economic Analysis] (arguing that cognitive errors may indicate that distributional goals can be pursued more effectively with non-tax legal rules rather than with tax rules). Some in the law and economics community also argue that redistribution beyond that which maximizes aggregate welfare is desirable. See Chris W. Sanchirico, Deconstructing the New Efficiency Rationale, 86 CORNELL L. Rev. 1003 (2001) (attempting to rebut Kaplow and Shavell and arguing for redistribution); see also Ronen Avraham \& Kyle D. Logue, Texas Versus Legal Rules: Redistributing Optimally, available at http://papers.ssm.com (last visited April 11, 2002). 
partly by a desire for analytical rigor that frowns on a detour outside the immediate confines of the subject and partly due to the notion that questions of distribution are the exclusive subject of taxation. Neither of these explanations, however, constitutes an excuse that justifies this conduct, particularly as Law and Economics holds a unique contribution to the quandaries of redistribution.

The fact that equal increases of wealth have greater impact when added to small, rather than large wealth, forms an argument for strong redistribution. Redistribution, however, distorts productivity incentives. Thus, we have an insoluble conflict regarding time-horizons. Redistribution will cause an immediate boost, but may hamper further productivity. Since from a long-term perspective productivity is paramount, the case for redistribution becomes much weaker. The first two parts of this essay, Parts II and III, introduce this contradiction.

The next part engages the propriety of delegating distribution exclusively to tax rules (Part IV). Concerns with distribution have been used to attack Economic Analysis of Law for ignoring distributional consequences. One response has been defensive, arguing that distributional issues should only be addressed by tax policy. ${ }^{4}$ Despite the formal accuracy of the statement that an optimal increment of taxation is preferable to a nontax rule that is equally redistributive but suboptimal, redistribution by nontax rules is often justified. Part IVA shows that even suboptimal redistributive rules can be preferable to an incremental aggravation of existing, sub-optimal, tax systems. Part IVB shows that redistributive rules can be preferable to even an optimal tax if they deter leisure activities (Part IVB1); if they do not induce a general, population-wide distortion of incentives (Part IVB2); if they operate on revealed skill, as might the example of public housing (Part IVB3); and, most importantly, if they redistribute welfare rather than funds, obviating thus the distortion of tax (Part IVB4). Potential examples of such rules are legal abortion, bottle laws, and the homeownership bias. Part IVB5 closes by observing that the features of rules that directly redistribute welfare are not within the conventional understanding of the function of taxation.

Rather than debating the desirability of redistribution that is obviously desired, beneficial, and underprovided, economic analysis can propose and has proposed methods for obtaining redistribution while bypassing the distortion that monetary redistribution creates. Part V explores the potential

4. See supra note 2 . 
of such concepts of "Coasean ${ }^{5}$ redistribution," effectuated by means of allocating rights, and of creating incentives that promote redistributive goals.

The contribution of this essay is the identification of several general cases of desirable redistributive rules in Part IV, and the exploration of further contributions by Economic Analysis of Law, through the development of rules that circumvent monetary redistribution. Each such redistributive rule puts one more cut in the Gordian knot of the conflict between taxation and growth. Each such redistributive rule that Economic Analysis may devise solves a piece of the contradiction that equality hurts efficiency.

5. Note that I use "Coasean" while some write "Coasian." This is a linguistic issue that depends on the root of the word. My view is that, just as Europe's residents are "European" rather than "Europian," Coase's irrelevance should be Coasean (akin to Burkean and Lockean theories). The answer should not depend on whether the root of the word "Coase" includes the final -e. Although I do not see any argument that the -e is excluded, the word "Coasian" cannot be the consequence of dropping that final -e. Even if the root of the word "Coase" were "Coas-" then Coase's irrelevance would be "Coasan" rather than "Coasian." Think of Tibet and Tibetans, or even Rome and Romans. One cannot object that Mars' imaginary residents are Martians or that college students are collegians. The root of "Mars" comes from the Latin genitive of the god of war: Mars, Martis. Similarly the root of "college" includes the -i as it comes from the Latin collegium. For "Coasian" to be correct, its users should be able to point to a word suggestive of a root with an -i ending, for example a Latin declination Coase, Coasis, which I doubt. While natural users of a language have the license to make incremental changes, 1 see no developing trend for converting the final -e of roots into an -i when deriving other forms of the word. If anything, the continued use of "European" shows the persnickety intransigence of roots even more than the use of "Martian" and "collegian," which trace back to their merely Latin origin. The final -e of the root Europe-comes from the ancient Greek, rather than the Latin "Europa." If "Europa" had supplanted the original root, it would have led to Europe's resident's being "Europans." Therefore, this essay uses "Coasean." Practice seems to agree more narrowly than expected; a search, on March 11, 2002, of the Westlaw database of law review articles (JLR) for "Coasean" produces 555 articles, while a full 406 use "Coasian" (28 articles use both without discussion, mostly because of the existence of both versions in titles of cited articles). The difference seems discussed by only an article not included in the above database. Stewart Schwab, A Coasean Experiment on Contract Presumptions, 17 J. LEGAL STUD. 237, 237 n.* (1988) (adopting the "Coasean" form and reporting that a LEXIS search produced 21-to-11 preference for "Coasean" in law review articles). Although Professor Ronald Coase appears to use "Coasian" in THE FIRM, THE MARKET, AND THE LAW 174 (1988), in a recent oral exchange with Professor Robert Lawless he indicated that he assumed the usage would be "Coasean." E-mail from Robert Lawless to Nicholas Georgakopoulos (April 5, 2002) (on file with author). This is fortunate, because if he preferred "Coasian" he would need to change retroactively his name to "Coasi" rather than argue that its root does not include the final -e. As the experience of the individuals formerly known as Rod Stewart and Prince may indicate, changes of names may not have retroactive effect. 


\section{REDISTRIBUTE!}

The importance of the distribution of wealth is not self-evident nor is it contradictory to economic analysis. On the contrary, economic analysis has shown its importance, which springs from the phenomenon of diminishing marginal utility of wealth. This "diminishing marginal utility" is a feature of the utility functions that reflects the reaction of each individual's utility or happiness to changes in the world, in this case to changes of wealth. Economic analysis does not abandon the subject of redistribution at that point, but proceeds to justify freedom of contract and the freedom for individuals to alienate their wealth and to benefit from exchanging it for the products or services they provide. Economic analysis, however, must not stop at the laissez-faire rejection of complete redistribution and forget its importance for aggregate welfare.

Utility functions are constructed to capture or reflect individual tastes. The usefulness of constructing utility functions is that they allow a more precise analysis of choices. Although they have the defects of any attempt to simplify a complex process, they are of profound use. They are, by design, the constant but also unobservable guide of individual decisions. The utility functions that are of interest here take a single input, wealth, and produce a single output, utility. All other being equal, more wealth is better than less. The way by which utility increases in response to increases of wealth, has a notable feature that is captured by the notion of diminishing marginal utility of wealth.

Diminishing marginal utility of wealth means that equal incremental increases of wealth produce different and diminishing increments of welfare, which is an accurate description of attitudes toward wealth. ${ }^{6}$ This leads to a

6. Risk aversion defines the shape of the function of utility of wealth. The coefficient of risk aversion determines the curvature of the function, which is a solution to a differential equation of the given type of risk aversion, most realistically, constant relative risk aversion. Coefficients of risk aversion much above four are not considered realistic. See, e.g., Rajnish Mehra \& Edward C. Prescott, The Equity Premium: A Puzzle, 15 J. MONETARy ECON. 145 (1985). For some applications in legal issues and further citations, see, for example, Lawrence Blume \& Daniel Rubinfeld, Compensation for Takings: An Economic Analysis, 72 CAL. L. REV. 569, 587-88 (1984) (collecting citations in note 99); Nicholas L. Georgakopoulos, Frauds, Markets and Fraud-on-the-Market: The Tortured Transition of Justifiable Reliance from Deceit to Securities Fraud, 49 MiamI L. Rev. 671, 693 n.36, 699 n.50 (1995) (showing that risk aversion influences traders' capacity to correct prices); Nicholas L. Georgakopoulos, Meinhard v. Salmon and the Economics of Honor, 1999 ColuM. Bus. L. REv. 137, 161 (showing that risk aversion implies that broad fiduciary obligations are desirable). 
strong argument that redistribution of wealth would increase total welfare. ${ }^{7}$ Giving to the poor tends to increase their welfare (or utility) more than the reduction caused by withdrawing the same increment of wealth from the rich. The strength of the argument about diminishing marginal utility of wealth is visible in its graphical representation. The following graph depicts wealth along the horizontal $\mathrm{x}$-axis while the vertical $\mathrm{y}$-axis represents utility, welfare, happiness. The first few incremental increases of wealth, such as the one from point $W_{1}$ to $W_{2}$, produce large increases of welfare, such as the one from $U_{1}$ to $U_{2}$. Equal increases of wealth being added to larger wealth, such as the one from point $W_{3}$ to $W_{4}$, lead to smaller increases of welfare, from $U_{3}$ to $U_{4}$. This pattern continues, and further incremental increases of wealth have an ever smaller effect on welfare.

7. This is not a novel proposition, dating from over 100 years ago. See F.Y. Edgeworth, The Pure Theory of Progressive Taxation, in Economic JusTiCE 371, $373-74$ (E. Phelps ed., 1973). 


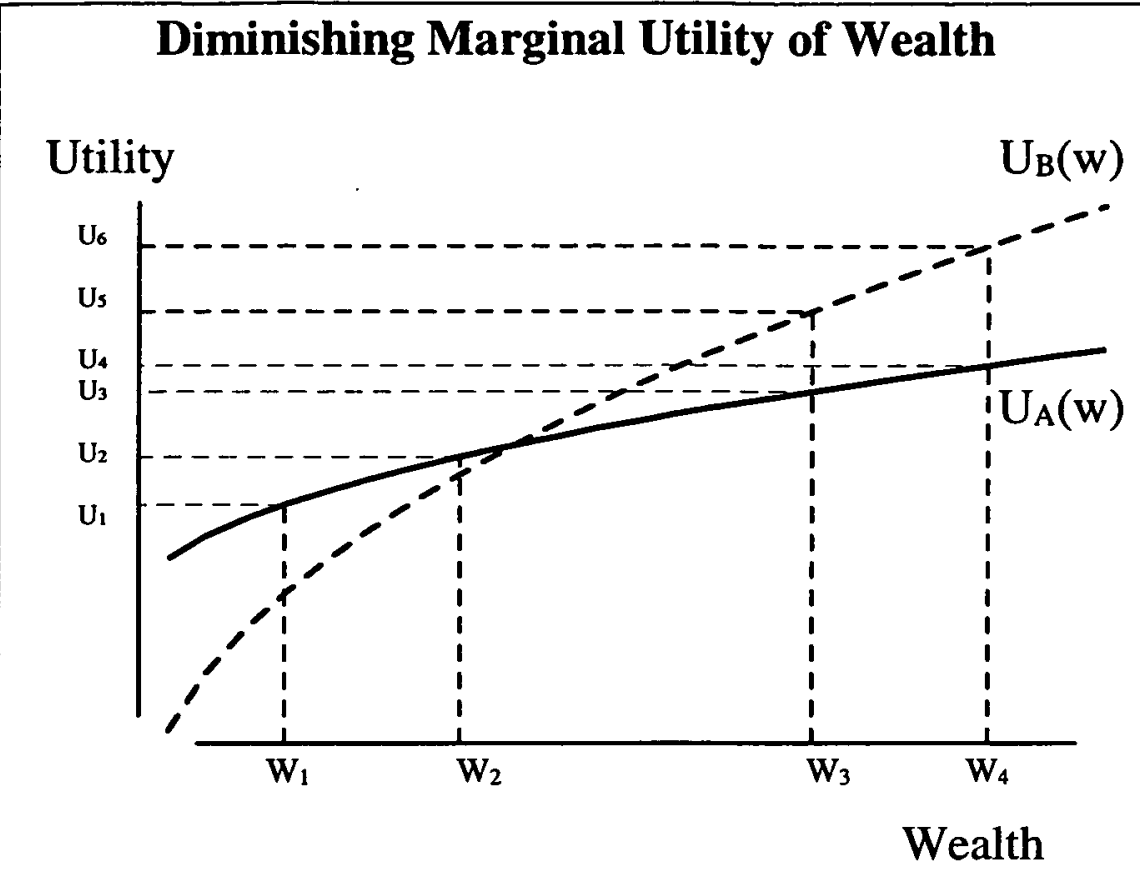

This figure depicts diminishing marginal utility of wealth. As wealth increases along the $x$-axis, utility (welfare, or happiness) is given by the function $U_{A}(w)$ and also increases. However, equal incremental changes of wealth have larger impact when they occur under small wealth (such as the change from $W_{1}$ to $W_{2}$ ) than under large wealth (from $W_{3}$ to $W_{4}$, which produces a smaller increase in utility). This is the diminishing effect of wealth on utility, which forms a strong argument for redistribution. A second utility function is displayed with a dashing line, $U_{B}(w)$, which is more sensitive to changes of wealth. According to the objection that utility functions of different individuals are not identical, redistribution may reduce the wealth of an individual who is sensitive to wealth, such as the one whose utility is determined by $U_{B}(w)$. If redistribution reduces this individual's wealth from $W_{4}$ to a wealth of $W_{3}$ so as to produce an increase from wealth $W_{1}$ to wealth $W_{2}$ in someone whose utility follows $U_{A}(w)$, it is conceivable that this redistribution may not increase aggregate welfare. It is takes from someone who is very sensitive to wealth and gives to one who is nearly indifferent to wealth. The utility of the former would be reduced from $\mathrm{U}_{6}$ to $U_{5}$ which may be more than the utility of the latter is increased, namely from $U_{1}$ to $U_{2}$. The weaknesses of this objection to redistribution are discussed in the text.

Some have objected that the argument for redistribution that is based on the diminishing marginal utility of wealth is inaccurate because the 
increments of utility of different people cannot be compared. ${ }^{8}$ Since different individuals' utilities are unknown, diminishing marginal utility of wealth only argues that aggregate welfare would increase if wealth were redistributed among individuals whose utilities respond to wealth in identical ways. Since individuals' happiness is strongly idiosyncratic, redistribution may take from wealthy individuals amounts that contribute more to their happiness than to that of the recipients of the redistribution. ${ }^{9}$ While this objection is valid in theory, the pragmatism of its practical application circumvents it easily. First, this objection is extremely unlikely to be true in general because general redistribution takes from many wealth to give to many poor. Although some avaricious wealthy may place very high value on their last few dollars, it is virtually inconceivable that the last $\$ 10$ wealth is on average enjoyed more by all wealthy than the same amount would be enjoyed, on average, by the poor recipients of redistribution.

Moreover, although the objection would validly preclude complete redistribution, it is not valid when leveled against the partial redistribution that is desirable. To clarify this objection to redistribution, suppose that enough redistribution has taken place that the rich half of the population is richer than the poor half by two dollars. Taking one more dollar from the rich half and giving it to the poor half would achieve complete redistribution. This last piece of redistribution may well not increase aggregate welfare, because this dollar is hardly certain to be more enjoyable to the poorer half. When the two levels of wealth are so close it is likely so easy to move from one to the other that the composition of the groups is a matter of choice of effort rather than being a matter of skill or chance. The

8. See, e.g., Bernard Williams, A Critique of Utilitarianism, in J.J.C. SMART \& Bernard WILLIAMS, UtILITARIANISM: For AND AGAINST 75 (1973); Mark Geistfeld, Reconciling Cost-Benefit Analysis with the Principle that Safety Matters more than Money, 76 N.Y.U. L. Rev. 114, 135-36 (2001); Amartya Sen, Utilitarianism and Welfarism, 76 J. PHIL. 463 (1979); see also UTILTARIANISM AND BEYOND (Amartya Sen \& Bernard Williams eds., 1982) (collection of essays by leading proponents of differing views). A retum to the notion that utility can be aggregated, however, has at least one prominent supporter among economists. See John C. Harsanyi, Cardinal Utility in Welfare Economics and in the Theory of Risk-Taking, 61 J. Pol. ECON. 434 (1953); John C. Harsanyi, Cardinal Welfare, Individualistic Ethics, and Interpersonal Comparisons of Utility, $63 \mathrm{~J}$. POL. ECON. 309, 317 20 (1955); John C. Harsanyi, Nonlinear Social Welfare Functions: Do Welfare Economists Have a Special Exemption from Bayesian Rationality?, 6 THEORY \& DECISION 311 (1975). Some contemporary philosophers also seem to agree. See, e.g., R.M. HARE, MORAL THINKING: ITS LEVELS, METHOD AND PONT (1981); J.J.C. Smart, An Outline of a System of Utilitarian Ethics, in SMART \& WILLIAMS, supra, at 1.

9. The impossibility of comparing interpersonal utilities is also rebutted by Adler \& Posner, supra note 3, at 196, 204-09 (with further citations). 
choice to belong to the richer group is made by those who derive the most utility from that additional margin of wealth and, therefore, taking from this group is taking from individuals whose utility is more sensitive to wealth, and giving to other group is giving to the group that is less sensitive to wealth. Thus, the potential for different enjoyment of wealth among individuals does rebut an attempt to use diminishing marginal utility of wealth as an argument for complete redistribution. Complete redistribution is undesirable on several other grounds, however, as shown below.

The same argument (that the wealthy may on average be so much more sensitive to wealth that redistribution reduces aggregate welfare) is not persuasive when leveled against partial redistribution. Some of the poor may be very sensitive to wealth but unlucky or unskilled and some of the wealthy may not be particularly sensitive to wealth but may be very skilled or lucky. Accordingly, the membership in the two groups is mixed. When taking all members of each group into account, although the wealthy group may have some extra individuals of high sensitivity to wealth, it also contains some who are relatively insensitive to wealth. Similarly, although the poor group may have some extra individuals who are relatively insensitive to wealth, it also contains some who are very sensitive to wealth. Even if the two groups have somewhat different membership, the membership is not dominated by sensitivity to wealth. Therefore, although some redistribution would be taking from those who are sensitive to wealth and giving to the relatively less sensitive and may reduce aggregate welfare, much redistribution takes from those who have been lucky or skilled, and gives to those who have not had luck and skill. Partial redistribution is still justified because it takes increments from those of deep wealth, reducing utility relatively little on average, and gives increments to those of small wealth, increasing utility much, on average. Therefore, the inconclusive nature of close comparisons of utility does not argue against redistribution that stops well short of complete redistribution.

\section{DO NOT REDISTRIBUTE!}

With the same breath, however, economic analysis rushes to counter these arguments. While redistributing wealth may increase total welfare, much greater increases of welfare can be achieved by increasing productivity. The evolution of human well-being over the last few hundred years shows the inescapable truth of this. Human welfare has increased much less from redistribution efforts, such as the French or Communist revolutions, than by increases in productivity, such as the industrial 
revolution, mass transportation and communication, or the information revolution. The effect of redistributing revolutions can even be argued to be negative. ${ }^{10}$ The economic explanation would be that they eroded productivity incentives. The existing productivity incentives of the previous system-in both France and Russia, a feudal system-were destroyed by these redistributing revolutions, which were not able to produce a satisfactory new web of incentives for advancing productivity. Redistributing existing wealth may produce a one-time increase in welfare, but an erosion of productivity incentives is a permanent handicap, the cumulative effect of which, over decades and centuries, is massive.

The failure of the redistributing revolutions underscores the point that the well being of humanity depends on production rather than capital. In the most elementary terms, survival depends on the production of food, but even in sophisticated societies, welfare depends on the production of goods and services. Because humanity's immediate need is for products, rather than the means that produce them, wealth as capital is a derivative of its product. Capital has value only because of the product it generates; idle capital has value only because of its potential to generate product if it becomes active. Thus, the first problem with redistribution is that, to the extent it redistributes capital or potential capital, it may influence productivity. The other much more important and widely recognized problem is that redistribution schemes interfere with the incentives for productivity.

Redistribution influences productivity incentives because it breaks the connection between individuals' productive efforts and their welfare. A complete redistribution would require the absence of private property and equal distribution of all social products. We must compare the incentives under these circumstances to incentives under systems where individuals appropriate their own product or benefit from their productivity. ${ }^{11}$

10. A string of statistical papers show the superiority of common law and of Scandinavian legal systems over German and, more emphatically. French legal systems. Although the authors attribute the differences to various details of business law, the correlation with a past of redistributive revolutions is striking. See Simon H. Johnson et al., Tunnelling, 90 AM. ECON. Rev. 22 (2000); Rafael LaPorta et al., Law and Finance, $106 \mathrm{~J}$. Pol. ECON. 1113 (1998); Rafael LaPorta et al., Legal Determinants of External Finance, $52 \mathrm{~J}$. Fin. 1131 (1997); Rafael LaPorta et al., The Quality of Government, 15 J. L. EcoN. \& ORG. 222 (1999).

11. My effort to avoid terms that refer to property concepts is as obvious as it is futile. The difficulty of stating the idea of "benefit from effort" without using terms referring to ownership and property is apparent and not at all coincidental. The acquisition of a property right in the product of one's labor is a simple and nearly perfect incentive to produce. Many societies, however, develop norms of sharing the appropriable product of an individual's 
Obviously, individuals whose product will be shared have incentives that differ vastly from those of individuals who will enjoy exclusively the fruit of their labor and whose enjoyment, therefore, is tied to their productivity.

Enjoying the fruit of one's labor makes the private welfare of each individual depend on the value that each produces. Sharing the redistributed product makes the private welfare of each individual depend on avoiding personal effort and relying on the efforts of the other members of the society. Thus, redistribution produces an incentive for every member of society not to be productive. Even if some or many members do not succumb to this incentive, others will and social product will be lost. The legal system must address the incentives not of the noble-minded but of those with comparatively more base motives, which echoes vividly in the views of the Laws and Economics scholar Justice Oliver Wendell Holmes regarding the "bad man's" law. Holmes considered that the law must be written and interpreted from the perspective of the "bad man" because the law had to thwart his efforts to circumvent it. ${ }^{12}$ Similarly, the economic incentives that the law gives must be viewed from the perspective of the "bad" or, rather, self-interested and irresponsible persons, who would not voluntarily perform their share of society's work. According to the Law and Economics view, Holmes' warning can be written: The law must be designed for the "irresponsible man."

In addition to distorting the productivity incentives of individuals, redistribution may interfere with the productivity of capital. This problem is a result of the redistribution of capital, rather than the redistribution of product that caused the distortion of productivity incentives that was analyzed above. Thus, it only arises when the social planner, persuaded that redistribution of income is undesirable because it erodes incentives, inquires into why the wealth that has already been accumulated should not be redistributed, leaving future income to produce its incentives without distortions. The simple objection can be that without a commitment that such a redistribution will not happen often, individuals will react to the

labor, for example, the hunter's kill. The existence of such norms might be offered as a counter example, but it is not. The individuals who share the appropriable fruit of their labor are usually compensated with various tangible and intangible benefits. Evolutionary anthropology delights in finding examples of such apparently altruistic conduct that gets very tangible rewards. For an entertaining narrative of such "trades," see JARED M. DIAMOND, WhY Is SeX Fun? The Evolution of Human SeXuality (1st ed. 1998).

12. Oliver Wendell Holmes, The Path of the Law, 10 Harv. L. REv. 457, 459 (1897) ("If you want to know the law and nothing else, you must look at it as a bad man, who cares only for the material consequences."). 
possibility of occasional redistributions of wealth the same way as to the redistribution of income. Even if wealth redistribution is rare enough-for example, if it is only acceptable in the form of an estate tax-it has negative consequences. It indirectly biases individuals toward consumption as opposed to investment, and it directly distorts the allocation of resources away from capital and toward consumption.

Individuals react to an anticipated redistribution of wealth by devaluing income that capital assets will produce after the redistribution. Thus, capital assets are less valuable to individuals than is the value of the capital asset to society. When individuals decide whether to save by investing in a capital asset or to consume, consumption will appear more appealing to an individual than it is from the perspective of society. Society, of course, will exist after the redistribution and value the income that invested capital would have produced after that date. Sophisticated markets for capital assets will mitigate this problem, because they may allow a sale of the assets before the redistribution and consumption of the proceeds. Nevertheless, the problem will persist for any assets that are not trading in a nearly perfect market. Even in our environment of advanced markets, this exception clearly includes family businesses. An example illustrates this distortion on investment and the potential salutary effect of capital markets.

Imagine that society as a whole has determined that it would give up consumption of 10 loaves this year in order to obtain 11 next year. Thus, society considers $10 \%$ an adequate compensation to forego immediate consumption and interest rates are at $10 \%$. An entrepreneur has a business which can be made more productive by an investment. The increase in productivity is $11 \%$ of the invested amount. Thus, an entrepreneur with no concern about enjoying any part of the future value of the business, would make the investment. Not only is foregoing consumption justified by the future gains, but our entrepreneur would also borrow at $10 \%$, invest, and the $11 \%$ product would cover the interest and leave a profit. The investment, of course, is also socially desirable, since society would give up consumption for an $11 \%$ total gain, even if it were divided $10 \%$ to the provider of capital and $1 \%$ to the entrepreneur.

Fear of wealth redistribution will prevent this socially desirable investment. Suppose the entrepreneur will die this year and knows that his heirs will pay a $10 \%$ tax on the value of the business. Now the investment is no longer sensible for the entrepreneur's family. By foregoing consumption of, say, 100 loaves, they would be able to make 11 more loaves every year, which corresponds to an increase in the value of the business by 110 loaves (the 11 loaves annually, capitalized at the $10 \%$ rate). They will not enjoy this 
increase in value, however. After the $10 \%$ tax on the increased value, they will only net a value of 99 . The same decision would be made if they tried to borrow 100 . The product of 11 would be more than sufficient to pay the interest, but after the payment of the tax, the family cannot repay the loan. ${ }^{13}$ Thus, redistribution distorts investment incentives and socially desirable investments will not be made.

A market would induce the correct decision by the entrepreneur only if full value could be had for the business. But if the buyers are to be induced to buy, selling entrepreneurs will have to accept a discount. Full value in this case would be 110 loaves, i.e., the value of the future production of 11 loaves annually, discounted at $10 \%$. If the discounts and transaction costs of the market imply that the entrepreneur will receive $10 \%$ less than full value, the investment is still unattractive, because it requires an investment of 100 and can be sold, net of costs and discounts, for 99 (that is, $90 \%$ of 110 ).

Wealth redistribution also directly distorts the allocation of resources away from capital into consumption. To the extent that it means taking from the rich and giving to the poor, redistribution of wealth likely takes capital and gives consumption. This is true because the wealthy who are being taxed do not put their first but their last dollars into capital investment, while the poor, who receive them, have a strong incentive or bias to consume them rather than invest. ${ }^{14}$

Interposing the state with a welfare system does not necessarily change this problem. The state would still collect funds, a big part of which would have gone into investment, and would turn those funds into immediate consumption of health, retirement, or housing services. A different description of this effect is that the state takes funds from users with low discount rates-the rich for whom additional consumption today is of little interest-and gives them to users with high discount rates-the poor who would improve their lot immediately rather than take a chance on the future. This is not to say that saving is inherently better than consumption; the socially optimal compromise between saving and consuming must be made.

13. Of course, if this is a loan to the business or the entrepreneur, rather than a loan to the family, the distortion does not arise. We are already, however, entering a situation of sophisticated transacting. Not only does a norm of paying progenitors' debts likely exist, but we are also ignoring the numerous costs of borrowing, such as the cost of entering into the transaction and the increased risk of insolvency to which borrowing exposes the business.

14. Indeed, as if to avoid this problem, much redistribution is forced into investment, so that the poor are given education rather than funds with the option to either spend them on education or in consumption. This also confounds statistical attempts to measure the impact of taxes and redistribution discussed below, infra note 62 . 
The hypothetical estate tax creates a bias in favor of consuming, which arguably wastes socially desirable investment opportunities. ${ }^{15}$ Nevertheless, this argument should not be understood to consider the estate tax as undesirable. ${ }^{16}$

One might counter that redistribution does not influence incentives because the acquisition of wealth is random. ${ }^{17}$ If the acquisition of wealth were a truly random lottery, redistribution would simply reverse the results of the lottery with no effect on incentives. Wealth creation, of course, is not truly random as it also depends on many other factors such as effort, ambition, and skill. Under the lottery scheme, the tax rate should be

15. Perhaps one could argue that the state's welfare system would not produce this bias if it were structured akin to a defined contribution retirement plan, but this is impossible. Defined contribution plans contrast with defined benefit plans, in which the benefit that individuals receive does not depend on the accumulation of their savings. A defined contribution plan, by contrast, means that benefits are solely the product of savings that have accumulated. This concept, however, does not lend itself to applications outside the retirement setting. In what sense can the young welfare recipient have saved so that the redistribution received is the product of some contribution? This redistribution should more appropriately be considered an insurance scheme, where all pay a premium to avoid the dire situation, and the welfare recipient is simply the unlucky one who receives the insurance payment. Insurance, however, causes distortions of its own. In the setting of a plush welfare scheme, a concern is that it mitigates the incentive to avoid welfare. Contractual insurance tries to avoid this "moral hazard" problem in various ways, including only compensating accidental harms as opposed to intentional self harm, a concept that is again hard to apply to welfare unless one were to make welfare inversely related to skill, a proposal that will also fail.

16. This discussion should not be read to imply that the estate tax is particularly unappealing, because the estate tax may have advantages compared to other types of taxation. The advantages become obvious if we focus on the inheriting generation. To the extent the tax creates a bias in favor of spending and donating wealth to charitable causes, it reduces heirs' dependence on inherited wealth and creates incentives for the heirs' productivity. Moreover, if we are inherently overoptimistic-as psychological studies of cognitive biases show-then this is the tax least likely to influence incentives. All taxes create biases, but a tax that people expect to pay later than they actually do would distort incentives the least. A similar argument has been used to attack the notion that redistribution should only be pursued by the tax system. To the extent that uncertain events are underestimated, redistributing wealth by means of legal rules that apply rarely, perhaps such as tort liability, will have less of a distortion on incentives than a tax, which applies with certainty. See Jolls, Behavioral Economic Analysis, supra note 3 , at 1656.

17. A comprehensive survey of the theories that produce unequal wealth also discusses the possibility of randomness (called the "Stochastic Model" of wealth) and finds that they are refuted by the evidence. See Gian Singh Sahota, Theories of Personal Income Distribution: A Survey, 16 J. ECON. LIT. 1, 8 (1978) ("In one of the most comprehensive tests of stochastic theories ... finds significant evidence against practically all the major assumptions of these models."). 
inversely related to the deterministic contributors to wealth creation such as effort, and skill, so that the one who exerted greater effort, and skill of two equally rich individuals, should be taxed less. ${ }^{18}$ Nevertheless, a socially undesirable bias would still exist. Some activities involve highly risky and uncertain rewards and such a policy would deter them. Take oil exploration or filmmaking. The rewards from the activity are so unpredictable that it can be analogized to a lottery in which winning is weakly related to skill or ambition. Entrepreneurs search for oil only because they could benefit from "winning the lottery." A redistribution scheme that takes the gains away for not being the product of skill, ignores that entrepreneurship and the creation of value is also a matter of taking chances. If society does not let the winner keep chance's reward, society will be missing chances for gains. ${ }^{19}$

18. This concept would also preclude actual lotteries, betting, and games of chance. Note that the determinants of wealth creation in the sentence of the text do not include ambition, which has an ambivalent reception in the tax literature, which seems to suggest that wealth created by ambition but without effort and skill should also be taxed more heavily. Unless ambition is considered an affirmatively undesirable motive, the analysis of the taxation of wealth accumulations due to luck that follows in the text, will also apply to the taxation of wealth accumulations due to ambition.

19. Entrepreneurial risk-taking and wealth accumulation as a consequence of chance are identical concepts. For example, one cannot argue that gains from entrepreneurial risk-taking should be taxed more because every individual who was exposed to the same risk would enjoy the same reward. As a matter of probability, out of the numerous risk-takers, only the lucky ones enjoy the rewards. If the reward occurs with $10 \%$ probability, for example, this implies that only one out of every ten risk-takers will enjoy the reward. Neither does conditioning the answer on a choice to accept to risk change the issue. Answering that the entrepreneurs who chose to take the risk should still be entitled to the reward, does not negate probability theory, for not every uncertainty is consciously accepted. For example, if accidental good luck, such as the discovery of penicillin while conducting other chemical experiments were taxed, then conducting chemical experiments would be deterred. If conducting chemical experiments tends to induce uncertainty - bad burns, for example, as well as valuable discoveries-such a tax would deter chemical experiments and the associated but remote gains of society. Conversely, compensating the burns would overly encourage an activity that may be undesirable on an expected value perspective. For attempts to adjust for luck, see generally, Donna M. Byrne, Locke, Property, and Progressive Taxes, 78 NEB. L. REv. 700, 724 (1999) ("Differences in . . . willingness to take risks result in differences in accumulation, but these differences are acceptable because they result purely from individual choice; everyone could accumulate as much as the person who accumulates the most, if they were willing to expend the effort or make the same sacrifices." (emphasis added)); Donna M. Byrne, Progressive Taxation Revisited, 37 ARIz. L. REV. 739, 779-81 (1995); Ronald Dworkin, What Is Equality? Part 2: Equality of Resources, 10 PHL. \& PUB. AfF. 283, 292-96 (1981) (distinguishing chosen uncertainty, labeling it "option luck" and allowing it to run its course, from unchosen uncertainty, labeling it "brute bad luck" and requiring rectification of its losses; not mentioning "brute good luck"); 
The conflict between the idea that redistribution increases welfare and the realization that it also destroys productivity is stark and insoluble. It may be an inescapable conflict of organized society, although this essay argues that the legal system can improve this compromise. The unavoidable potential for different compromises between redistribution and productivity in different jurisdictions, produces further distortions. Jurisdictions that favor productivity will also receive the indirect benefit of attracting the most able and risk-tolerant individuals from jurisdictions that favor redistribution. This, of course, produces a collective action problem among jurisdictions that compete, in essence, for members with skill, energy, and risk-bearing capacity. Individual jurisdictions choose less redistribution than they would, because they seek to avoid the flight of talent and risk-taking ability to others. An interesting partial remedy of this bias is to make contributions to international organizations inversely related to countries' taxation levels. Countries that tax less are recipients of "brain drain"-the other countries' skilled, or risk-tolerant-and have greater productivity at the expense of countries that favor redistribution. The greater payments can partly compensate for this bias. ${ }^{20}$

\section{DELEgATING REDISTRIBUTION TO TAX POLICY}

Once redistribution is accepted, be it as little or as much as each jurisdiction chooses to provide when compromising between future and current welfare, the question becomes how the legal system should provide it. This is an issue that has haunted Law and Economics analysis because the orthodox approach to Law and Economics analysis disregards the distributional consequences of rules. As a result, Law and Economics has been attacked for ignoring redistribution issues. ${ }^{21}$ One response has been that concerns about distribution should be addressed exclusively in the tax system.

Law and Economics scholars with a laissez-faireist streak have argued that taxation should be the exclusive means for redistributing wealth. ${ }^{22}$ The

20. For an attempt to improve distribution of wealth on a world-wide level, see Michael J. Graetz, International Income: Inadequate Principles, Outdated Concepts, and Unsatisfactory Policies. 54 TAX L. REV. 261 (2001), and 26 BROOK. J. INT'L L. 1357 (2001). International tax competition is not seen as a competition for individuals but for investments. See, e.g., Julie Roin, Competition and Evasion: Another Perspective on International Tax Competition, 89 GEo. L.J. 543 (2001).

21. See supra note 1.

22. See Kaplow \& Shavell, Clarifying, supra note 2; Kaplow \& Shavell, Redistributing, supra note 2; Shavell, supra note 2. 
foundation of the thesis is that using non-tax law to redistribute wealth distorts the operation of the markets. Therefore, redistribution by means of non-tax law reduces welfare. The conclusion is that redistribution, barring exceptional circumstances, should occur through taxation. This reasoning, despite being technically correct, is substantively false in at least two ways. First, actual taxation has large distortionary effects, making the premise false. Second, even the distortionary effects of an optimal tax outweigh the distortions of several kinds of non-tax redistribution.

The model that is offered as proof of the superiority of redistributing through the tax system is very simple. Suppose that an optimal substantive (non-tax) rule exists, but an inferior one may provide some additional redistribution. Compare the adoption of the redistributing rule to maintaining the optimal rule while using the tax system to achieve the same redistribution while producing the least possible distortions on incentives. We are told that the latter alternative is superior. Due to the efficient rule and the minimized distortive tax, society is better off than under a suboptimal rule and non-minimized distortions of taxation.

It should be obvious that this thesis is a truism. Tax is assumed to produce distortions equal to those of the redistributive effect of the non-tax rule. ${ }^{23}$ A more accurate model should acknowledge that the additional tax

23. For example, Kaplow \& Shavell posit:

suppose that high-income individuals are subject to an income tax of 30 percent and that, in principle, further redistribution to the poor would be desirable. Would we want to adopt an inefficient legal rule because it redistributes an additional 1 percent of high earners' income to the poor? Under such a regime, high-eaming individuals would surrender 31 percent of each additional dollar of income: 30 percent would go to the tax authority, and 1 percent would be taken by the legal system. Now assume, instead, that an efficient legal rule is retained and the income tax rate for high earners is raised to 31 percent. Then they would be in the same position and would be induced to work the same amount as under the inefficient regime. (The increase in the tax rate from 30 to 31 percent does not reduce their incentive to work because it is offset by the 1 percent decrease in the implicit tax that was associated with the inefficient legal rule.)

Kaplow \& Shavell, Redistributing, supra note 2, at 667 . Note however that this hypothetical establishes a comparison between equal distortions. Both the tax and the non-tax redistribution are achieved by a $1 \%$ increase in the marginal tax rate. Hence, they both have the same consequence for incentives and both distort the choice between work and leisure the same way. Several non-tax rules examined in Parts IV and V achieve redistribution without being equivalent to a tax increase, hence, without distorting the choice for work versus leisure.

A different attack on the Shavell side's model rests on the notion that neither inefficiency nor redistribution are obtained in discrete intervals. Suppose we had the optimal rule and tweaked it very slightly-infinitesimally-in favor of more redistribution. If redistribution is 
may cause greater distortions than the non-tax rule, particularly as long as taxation takes the wasteful shape of increasing marginal tax rates. An increase of an inefficiently designed tax burden should be considered likely to induce a greater distortion than any distortion caused by the redistributive rule. Then, the comparison is of two different compromises between wealth and redistribution. Using the optimal non-tax rule with a more distortionary tax regime to redistribute wealth must be compared to using a less distortionary, but redistributive rule, with a less distortionary tax system. The conclusion is that either compromise may be superior.

A graphical representation of this dispute helps resolve the different claims. The graph would have two dimensions. One would be redistribution and the other would be the substantive function of the non-tax rule at issue. ${ }^{24}$ In the example of torts, the metric may be the total cost of accidents, namely the cost of care to avoid accidents plus the cost of injuries from accidents that do occur. The optimal tort rule minimizes total accident costs, and the dispute is whether a tort rule that redistributes some more is preferable to a combination of the optimal tort rule and some more taxation as to produce the same amount of additional redistribution.

The graph that proponents of redistribution-by-non-tax-rules (the opponents of the Shavell position) envision has a peak at some point where accident costs are the smallest and only the inherent redistribution is provided by the rule. The graph has three dimensions but is presented as we look "down" so that the third dimension is not visible. The dimension that is not visible is the social welfare that the rule produces and we can think of it as the "altitude" of a "mountainous" surface. The two visible dimensions are accident costs and redistribution. Accident costs reach a minimum at the

desirable, the new rule is likely superior. Chris W. Sanchirico, Should Legal Rules Be Used to Redistribute Wealth? Taxes Versus Legal Rules as Instruments for Equity: A More Equitable View, 29 J. LEGAL STUD. 797 (2000); see also Sanchirico, supra note 3. Maximization, however, means that even an incremental move away from the optimal does reduce welfare, as Shavell's side explains. Kaplow \& Shavell, Clarifying, supra note 2. Furthermore, some of the existing and proposed redistributive rules that do not distort incentives which are discussed in Parts IV and V, however, do not fit this mold of incremental improvements. They consist of improvements in distribution that cannot be imposed in arbitrarily small amounts along a continuum. Rather than being desired improvements of other rules, they are independent redistributive rules. The bottle laws that clean inner-city neighborhoods and the availability of abortion that preserves the educational opportunities of the less skilled teenagers are typical examples of improvements that are not incremental.

24. Thus, the figure makes a simplifying assumption that the rule has only one goal or aggregates all its goals into one metric; if the rule had more goals, they could be included but a graphical representation would be impossible. 
optimal tort rule, which is also associated with some amount of redistribution. This is represented by point $A$.

\section{Choices about Redistribution and Welfare}

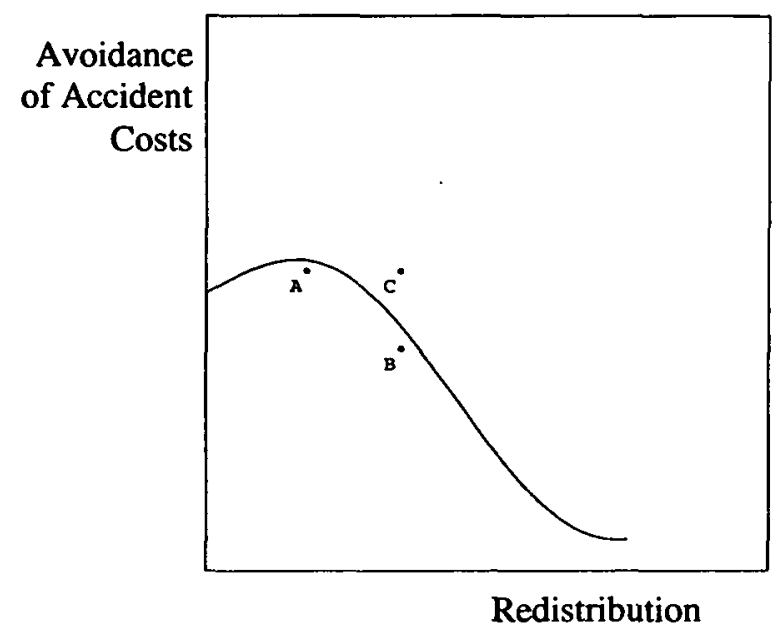

This is a graphical representation of the disagreement regarding whether only tax rules should redistribute wealth. Redistribution is represented on the horizontal axis and the avoidance of accident costs on the vertical. The optimal tort rule that produces the best outcome regarding accident cost avoidance also provides some redistribution that is represented by point $A$. The curve is the frontier of redistribution and accident cost avoidance that variations in the tort regime can provide. Proponents of redistribution would argue that increasing redistribution by changing the tort rule would increase welfare, even if it gave up some of the avoided accident costs. This would move us to point B, which, they would argue, may correspond to greater social welfare than the point $A$. Those who favor redistribution by means of the tax rules only, would counterargue that if $B$ produces more social welfare than $A$, then $C$ produces even more and is feasible. Point $C$ corresponds to the optimal tort rule (the one that produced $A$ ) with some additional redistribution achieved by means of the tax system. The problem with this argument is that greater taxation may distort markets and reduce welfare, so that $\mathrm{C}$ would not correspond to more social welfare than $\mathrm{B}$. Points $\mathrm{A}$ and $\mathrm{B}$ should be on the "cost-avoidance and redistribution frontier" but are drawn slightly inside it for clarity.

The opponents of the Shavell position would now have us move to a slightly more redistributional tort rule, which would be suboptimal in terms of accident costs. By obtaining redistribution, this new position, although it produces more accident costs, is superior because of the additional 
redistribution it provides. In the graph, they would argue that if A corresponds to the optimal tort rule that minimizes accident costs, then point B, which is associated with greater accident costs, provides society with more welfare because it corresponds to more redistribution. Point $B$, in other words, is higher in total welfare terms than A.

The side of Shavell argues that point B is dominated, for two reasons. If total accident costs are greater, society's total welfare is reduced. No matter how this welfare is distributed, it cannot produce more welfare than redistributing the maximum wealth, which exists when accident costs are minimized. In other words, either welfare generated by redistribution cannot compensate for wealth lost to increased accident costs, or redistribution from reduced accident costs always produces more welfare than redistribution with greater accident costs.

The first view holds that point B is always lower (in terms of social welfare) than point $A$. Such a view is untenable if we believe redistribution increases welfare. Redistribution may well increase social welfare by more than the loss in terms of accident costs.

The second view holds that a third point exists, point $\mathrm{C}$, where redistribution is performed by tax while using the optimal non-tax rule, and that point $C$ is necessarily higher in total welfare terms than $B$. Because point $\mathrm{C}$ corresponds to the same lowest possible accident costs as $\mathrm{A}$, it has the same coordinate along the accident-cost axis. Because it entails more redistribution, it has a greater coordinate on the redistribution axis. In other words, regardless where point $B$ is, point $C$ is necessarily higher. This is correct if the tax system is the least costly mechanism of redistribution. A recent estimate of the cost of the distortion due to the income tax is $\$ 2.65$ per dollar raised. ${ }^{25}$ The idea that the costs of taxation must be taken into account when deciding its level is part of the conventional understanding of the economics of taxation, the seminal work being that of Pigou and dating from 1938.26 Just as different taxes produce different consequences in terms of distortions, different means of redistribution do too.

The side of Shavell explains that the distortion of the tax system is a distortion due to redistribution and any redistributive scheme will have the same distortion. In other words, whatever the relationship between point $B$ and point A, point B cannot be higher than C. Point B cannot be higher than $\mathrm{C}$ because $\mathrm{B}$ involves the same distortions due to redistribution and starts

25. See Martin S. Feldstein, How Big Should Government Be?, 50 NAT'L TAX J. 197 (1997).

26. A.C. Pigou, A Study in Public Finance (1928). 
from a lower (suboptimal) level of the cost of accidents. ${ }^{27}$ This is known as the double-distortion argument. ${ }^{28}$ An optimal rule will cause no distortions, but a tax, even if optimal, will distort incentives to work. A suboptimal redistributive rule causes a distortion by virtue of not being optimal, and a second distortion by a reaction identical to the tax.

For example, consider that a society consists of two individuals, a productive one (the skilled) who has high income and a less productive one (the klutz) with lower income. An income tax reduces productivity by inducing the more productive one to work less. Suppose the skilled makes twenty loaves each week and the klutz only makes five loaves.

An income tax rule can redistribute without interfering with the baking process, but it will deter work. Impose an income tax of $60 \%$ on the number of loaves over ten. If the skilled still produces twenty loaves, the income tax will take six and give them to the klutz. The klutz adds the six loaves to the five he makes and enjoys eleven, while the skilled enjoys fourteen. We need to treat the skilled as a self-interested person, however. Without the tax, the skilled enjoyed the last one of the twenty loaves barely enough to keep working. When the tax is imposed, the skilled knows he will not enjoy that entire loaf, and he prefers to rest or play. Whether the skilled will quit two, four, or six loaves before he would without the tax, we cannot know. Suppose that the skilled chooses to make fifteen loaves, giving three to the $\operatorname{tax}(60 \% * 5=3)$ but still enjoying twelve. The skilled has twelve loaves and a lot of rest, while the klutz has eight. The two together have fewer loaves than without the tax, but the distribution of loaves is more egalitarian, since the skilled has only four loaves more than the klutz. Despite that the reaction of the skilled to the tax is so petty and wasteful, this result is better than a wasteful redistributive rule.

Consider, first, a desirable rule. Suppose both bakers sleepwalk once every week, entering the other's bakery and, unwittingly, enjoying an early morning snack at the other's expense. The cost of this event is that the victim, weak without breakfast, makes two loaves less. The rule entitles

27. See Kaplow \& Shavell, Redistributing, supra note 2.

28. See, e.g., Sanchirico, supra note 3, at 1014. Sanchirico (as do Logue \& Avraham, supra note 3 ) argues that redistribution based on features or manifestations of skill and wellbeing other than income will not produce the double distortion. If non-clumsiness is such a feature, adjusting tort damages downward, it is argued, would not induce avoidance of work and income. Indeed it would not, but the skilled and well-off would have an incentive to distort their image toward clumsiness-take more risks and engage in more activity not just to take advantage of the lower cost of accidents, but also in order to appear clumsy. Hence, the proposal produces a new double distortion. It distorts not only the activity, such as care, but also the manifestation on which redistribution is based, such as the appearance of clumsiness. 
victims to get the breakfast that the other was baking. When the rule is imposed, the total loaves go up from sixteen back to twenty. Instead of a tax, now, tweak this optimal rule to get some redistribution out of it while reducing its efficiency. In addition to getting the other's breakfast, have the victim use the other's bakery for a day. The bakery of the klutz is a mess, the skilled does not benefit from the new rule, stays in his bakery, so the new rule costs nothing to the klutz. The bakery of the skilled is in perfect order each morning, ready to make four loaves. The klutz makes four loaves and keeps them, leaving the bakery a mess, and not capable of producing four loaves the next day. The tweaked rule has some waste. The skilled, petty that he is, responds to the potential daily loss the same way as to an income tax. The skilled leaves work earlier, and leaves the bakery slightly messy, making only three loaves each day instead of four. The weekly production of the skilled is not quite fifteen, because the mess the klutz leaves prevents the skilled from making three loaves; suppose he only makes one loaf, instead of three. The skilled makes thirteen loaves each week, five lost to the redistributive effect of the rule, and two lost to the inefficiency that the rule imposes. When the desirable rule is tweaked to provide redistribution, the skilled ends each week with ten loaves, thirteen that he made minus three that he paid for sleepwalking. The klutz ends up with eight loaves, five that he made and three that he got from the skilled. The result looks appealing from a redistributional perspective, perhaps superior to the tax, as the klutz has only three less than the skilled. Nevertheless, a tax would do better, argues the Shavell side. A tax would not produce the inefficiency of the loss of two loaves. Returning to the optimal sleepwalking rule and increasing the tax to $75 \%$ would further induce the skilled to cut back, and make, say, fourteen loaves. After giving three to the klutz, they have eleven and eight. The klutz has the same, and the skilled has one more. Although the tax chills the incentives of the skilled to work, it does not impose the inefficiency of the tweaked rule. The tax imposes one distortion while the tweaked rule imposes two. The tweaked rule is not superior to the optimal rule coupled with an additional increment of income tax that produces the same redistribution.

Based on this reasoning, Shavell's side argues that tweaked rules are not superior to optimal rules coupled with an additional increment of optimal income tax, although they allow that in exceptional cases they may be. This statement, however, is a truism since it essentially states that optimal rules plus the least possible reduction of the incentive to work is better than suboptimal rules plus an equal or greater reduction of the incentive to work. Akin to other truisms, it is useless, because the existing income tax is not 
optimal. Even wasteful tweaked rules can be desirable when compared with a suboptimal tax. Moreover, the exceptional cases are quite frequent. Frequently, redistributive rules are preferable to an equally redistributive program even if it were funded by an optimal increment of income tax.

\section{A. Desirability Under Sub-Optimal Taxation}

Income tax can be less than optimal in the reduction of work that it induces. Income taxes can be different in the schedules of tax rates that they impose. As income taxes deter work, different income tax schemes, applied to the same population, will induce different amounts of work and product. Naturally, smaller taxes will tend to deter work less than large taxes. The pursuit of the notion of an optimal tax, however, keeps constant the total revenues raised by the tax. Two different income tax schemes, that raise the same revenue, are compared by examining the total product of all taxpayers. The income tax that reduces incentives for work the least, will have the greater product, and would be preferred. Thus, that an income tax is optimal means that no other schedule of tax rates exists that deters work less than the optimal tax. Those who study optimal taxation agree that existing tax schemes are not optimal. 29

The defectiveness of existing tax schemes falsifies the thesis of the Shavell side, not in theory, but in practice. The defects of the existing tax scheme indicate that redistribution that rules provide cannot be compared to the ideal of a tax that deters work the least. The redistribution that rules provide will tend to deter work, since the rich lose some benefit from working. The substitute of this redistribution, however, will not be the ideal of the optimal tax. Society's alternative, in practice, is a haphazard tax system, which can be improved and the redistributive rule may constitute an improvement. The redistributive rule may well allow the reduction of tax rates. The reduction of tax rates that are not optimal implies that incentives for work are restored. The restored incentives would be by definition stronger than an equivalent reduction of an optimal tax. The redistributive rule will substitute its own redistributive scheme, which will deter work. Even if the redistributive rule deters work more than an optimal tax, the result can be superior to the alternative. Although the redistributive rule

29. A very readable introduction to optimal tax theory is offered by Lawrence Zelenak \& Kemper Moreland, Can the Graduated Income Tax Survive Optimal Tax Analysis?, 53 TAX L. Rev. 51 (1999). See also STEPHEN G. UTZ, TAX PolICY 236-45 (1993); Joseph Bankman \& Thomas Griffith, Social Welfare and the Rate Structure: A New Look at Progressive Taxation, 75 CAL. L. REV. 1905, 1959 n.219 (1987) (noting the assumptions of optimal tax literature). 
deters work, the reduction of tax rates reinstates incentive to work. Since the tax is not optimal, the reinstated incentives to work may outweigh the deterrence of work due to the redistribution of the rule.

To see this effect in the example with the bakers, we would need to add a third baker, average. The tax would deter the work of the average and the skilled (while an optimal tax would not deter the work of the most productive individual in society by imposing no tax on his last increment of income). ${ }^{30}$ Without the redistributive rule, the tax would have to be large and both the average and the skilled would reduce significantly the number of loaves they would make. Adopting the redistributive rule, wasteful as it may be, could be a gain. The tax could be eliminated (or just reduced) and the deterrence of work due to the redistributive rule could be less than under the tax.

Suppose that the average baker can produce twelve loaves, leaving the capacity of the skilled and the klutz the same as in the previous example. Start with a suboptimal income tax of $50 \%$ of the loaves over eight, to which the average responds by cutting back to ten and the skilled by cutting back to fourteen. The tax takes one loaf from the average and three from the skilled. Giving these four loaves to the klutz, who makes five, brings him up to nine loaves. Consider as an alternative a suboptimal rule that imposes redistribution that deters work less. The rule is that whoever makes more than ten loaves must submit to an inspection by the klutz. The klutz inspects by "tasting" four loaves and causing a fuss that prevents the production of two loaves. The response of the average to this rule is to cut back to ten loaves so as to avoid the inspection. ${ }^{31}$ For the skilled, however, cutting back does not make sense, he prefers to make his full capacity of twenty loaves, even if six are lost, four eaten by the klutz and two wasted due to the klutz's fuss. ${ }^{32}$ The result is that the skilled has fourteen, the klutz nine and the average has ten loaves. This is a superior outcome to the inefficient tax. The source of the efficiency is that the work of the skilled was not deterred, because the burden that the rule placed on the skilled operated as a sunk

30. See Zelenak \& Moreland, supra note 29 , at 55 (" $[0]$ ne of the few general results of optimal tax analysis is that the tax rate on the last dollars earned by the most able (that is, highest wage) member of society should be zero.").

31. Even if the average made all the loaves he could, the inspection would cost him six loaves. He prefers giving up two than losing six.

32. The reason that the skilled would not reduce the number of loaves is that, once he bakes more than 10 loaves, he keeps the entirety of each additional loaf. The skilled baker would either bake 10 loaves and avoid the inspection, or bake 20 loaves, suffer the inspection, and be left with 14 loaves. He prefers the latter if he would not sacrifice loaves eleven through fourteen to obtain the additional rest from baking only ten loaves. 
payment rather than as a proportional tax on every loaf. The klutz and the skilled are in the same position, and the average baker has one extra loaf. Despite that this redistributive rule is wasteful, because two loaves are lost, its deterrence of work is less than that of the suboptimal tax.

Existing tax schemes are far from optimal. They deter work a lot, perhaps more than some redistributional rules. Substituting such a redistributional rule for incremental tax reduction could produce a net reduction in the deterrence of work. Therefore, such redistributional rules would be desirable substitutes of taxes.

\section{B. Frequent Desirability Compared to Optimal Taxation}

To explore the possibility of desirable redistributive rules in the face of optimal taxation, build an example illustrating the case where the redistributional rules is conceded to be preferable to the optimal tax. This is the case of a bias that deters leisure and is discussed in the next subsection. This also reveals that distortions that are not general may be superior to an optimal tax, discussed in Part IVB2. Superior to an optimal tax are also rules that operate on revealed skills, as might the example of subsidized housing, discussed in Part IVB3. Most importantly, superior to an optimal tax are rules that redistribute non-monetary welfare, as might the examples of legal abortion, bottle laws, or the homeownership bias, discussed in Part IVB4. Part IVB5 closes this discussion by showing how tax rules, by definition, cannot perform these functions.

\section{Deterring Leisure}

Deterring leisure restores incentives for work. Imposing redistributive rules that deter leisure improves the incentives of the tax system even if optimal. To understand this effect we need to start with an example.

Start with a society where each individual has different productive capacity, like the bakers of the previous example, and impose an optimal income tax. Even the optimal income tax deters work, therefore some production is lost as some reduce work and devote more time to their favorite leisure activity, such as skiing. Those who feel some deterrence from work due to the income tax, reduce work because the tax makes work less remunerative and less appealing than leisure, skiing. This environment can be improved by a reduction in the income tax and a burden on leisure activities, such as excessive liability for accidents caused by leisure activities like skiing. As leisure becomes less appealing, the product of the 
society will increase as the tax-motivated skiers find some work preferable to skiing. The tweaked tort rule, however, causes some redistribution as well as induces more work. An attempt to return to the optimal tort rule and produce the same redistribution by an incremental increase of the income tax would fail. The higher tax rates along with the elimination of the excessive liability would lead tax-motivated skiers to reduce their work even more in favor of skiing. Redistribution, therefore, is achieved at a lower cost by the biased tort rule than by the tax system. 33

The superiority of this non-tax rule is conceded by the Shavell proponents. ${ }^{34}$ Their first answer could have been that the result is an undesirable distortion of the choice of the activity. ${ }^{35}$ They do argue, however, that the desirability of the distorted tort rule in this example is exceptional.

The redistributive tort liability of the example does alter the incentives to engage in the activity. This alteration, however, is small, is desirable, and is redistributive. The basis of the claim of an undesirable distortion is that the greater risk of liability is equivalent to an "excise" or "use tax" on the

33. For the argument that a related bias in favor of safety issues is desirable on redistributive grounds, see Geistfeld, supra note 8.

34. In a brief comment on optimal tax, Kaplow and Shavell concede that superior alternatives to the optimal income tax exist:

[T]axes or subsidies on particular commodities might have indirect effects that reduce the distortion of an income tax. In particular, by taxing complements of leisure and by subsidizing substitutes, one can reduce the labor-leisure distortion and thereby improve welfare by more than the inefficiency that results from distorted purchases of the taxed or subsidized commodities. ... Thus, although a complete and sophisticated analysis does not demonstrate that it could never be efficient to change legal rules from what narrowly seem to be the most efficient ones, there is no general argument for adjustments of a conventionally redistributive type.

Kaplow \& Shavell, Redistributing, supra note 2, at 680-81. The example of the text imposes tort liability on activities complementary to leisure. Thus, this redistributive feature is superior to even an optimal tax. The housing subsidy discussed in note 23 and the existing and proposed rules discussed in Parts IV and V, however, are redistributive and not complements of leisure. These nules are more than exceptions to a "general argument" against redistribution by non-tax rules. Instead of the Shavell position discouraging the development of such rules, this essay argues that Law and Economics scholars should pursue the creation of such rules.

35. The distortion issue does not receive appropriate attention when Shavell's side reiterates that the example is exceptional. Kaplow \& Shavell, Clarifying, supra note 2, at 829 (considering a subsidy to poor yachters a substitute of a more redistributive tax system). A subsidy to poor skiers or yachters would influence conduct and the choice of the activity, inducing them, perhaps, to reduce work. 
activity, causing an undesirable general reduction in its quantity. ${ }^{36}$ However, the threat of tort liability is unlike a tax on the activity because it does not burden the poor. The bankruptcy policy of the fresh start ensures that the poor skier or yachtsman, who is assigned the large tort liability, can discharge it. Thus, the implicit price increase due to the greater tort liability is not general but restricted to the rich, revealing that the redistributional rule in not equivalent to a use tax.

To the extent the tort liability distorts choice, the distortion is desirable. Among the rich, whom bankruptcy does not protect from the liability, ${ }^{37}$ the greater liability will change conduct. To the extent that the fear of liability deters some high-income individuals from the activity, this is a desirable distortion in favor of productivity and against leisure. Thus, redistribution by the excessive liability is desirable even compared to an optimal income tax. The optimal income tax would be the best alternative that the Shavell side could offer to the redistributive tort rule and would suggest an increase of income taxes so as to raise exactly the amount that the tort rule would redistribute. The increased income tax, however, would distort the decision whether to pursue work or leisure, inducing some to reduce work in favor of leisure. The result is undesirable because this implies a drop in productivity. By contrast, the fear of excessive tort liability has the exact opposite effect. The most productive individuals are induced to consider leisure less appealing, devote more time to work, and increase the national product.

Moreover, the distortion that the excessive tort liability induces has a desirable redistributive side-effect. Since only the rich fear liability, the rich will be led to engage in excessive care. The consequence is that the activity becomes safer for the poor who will suffer fewer accidents and need to engage in less precaution. To the extent the cost of precaution is inversely

36. Kaplow \& Shavell, Redistributing, supra note 2, at 681 ("[W]hether an activity should be penalized or subsidized depends on how the activity affects the labor-leisure choice, not on whether it is undertaken disproportionately by the rich."). The reduction of the activity would be undesirable because it would reduce total surplus from the activity. If ski lift tickets were $\$ 30$ but carried a $\$ 10$ tax surcharge, skiers who derive $\$ 31$ to $\$ 40$ or enjoyment from skiing lose the net $\$ 1$ to $\$ 10$ benefit they would have enjoyed after paying the $\$ 30$ ticket. Unlike a true change of prices, the tax means that producer surplus will not substitute the lost consumer surplus. Regions that can offer skiing at a cost of $\$ 30$ to $\$ 39$ do not become competitive, cannot sell tickets, and do not enjoy the net $\$ 1$ to 10 gain they would have if price were truly at $\$ 40$.

37. Bankruptcy law is available to everyone. It does require, however, that all nonexempt assets be used to pay all debts. It is the assets of the rich that make them subject to the liability, while the lack of assets of the poor allows them to invoke the protection of bankruptcy law. 
related to skill and the poor are poor because of lack of skill, the reduction in precaution may radically change the ability of the less skilled poor to engage in the activity, perhaps changing the required precaution from infeasible to feasible. Increased safety, reduced precaution demands, and feasible precaution are benefits that the excessive liability confers on the poor, making the activity more hospitable to the poor. Instead of the reduction in aggregate demand that a usage tax would induce, the excessive tort rule makes the activity more appealing to the poor, directly conferring a benefit, consumer surplus, to them. Not only is this desirable, but this benefit is redistributive in nature, in the sense that the poor participate more in the activity. Contrary to a use tax on the activity "undertaken disproportionately by the rich" 38 which would further rarify the activity, the redistributional tort rule democratizes the activity. The redistributive tort rule does not only redistribute funds, but it also directly redistributes enjoyment and welfare.

The example is not exceptional, despite that Shavell's side argues it is. ${ }^{39}$ The argument that the redistributive tort rule is exceptional takes us back to a comparison with an optimal income tax substitute. If the income tax were optimal, some use taxes, excise taxes, or commodity taxes may still be desirable, but they would be exceptional in a world without uncertainty. ${ }^{40}$ The excessive tort liability from leisure accidents may be desirable, but would be claimed to fall in the same exception. Occasionally, use taxes can be desirable in an optimal tax environment, because the optimal tax is still an income tax that reduces incentives to produce, that distorts the decision for work or leisure in favor of leisure, reducing aggregate product. Use taxes

38. Kaplow \& Shavell, Redistributing, supra note 2, at 681 .

39. Id. at 681 (" $[$ T] $]$ here is no general argument for adjustments of a conventionally redistributive type.").

40. The general futility of taxes on "commodities" (used in abstract, hence including a use tax of the type discussed here) is shown by David E. Wildasin, Distributional Neutrality and Optimal Commodity Taxation, 67 AM. Econ. REv. 889 (1977).

Recent scholarship, however, shows that if individuals are uncertain about their future prospects, an optimal tax regime does include commodity taxes. A model of two goods, one necessary (for example, housing) and one discretionary, shows that the optimal taxation regime includes a subsidy on the necessary good. A rough estimate of the optimal subsidy on housing is calculated at about $25 \%$ ! See generally Helmuth Cemer \& Firouz Gahvari, Uncertainty, Optimal Taxation, and the Direct Versus Indirect Tax Controversy, 105 ECON. J. 1165,1178 (1995) ("'[R]elative to other goods, housing prices must be subsidized by as much as $25 \%$."). Pursuing the notion that uncertainty justifies taxes on discretionary goods and services, while arguing for a subsidy on goods and services that are necessary, can easily be imported into law. Liability from accidents arising from the ownership of houses, such as slipand-fall accidents on icy sidewalks, could, arguably, be reduced or eliminated as a subsidy to housing. 
can be desirable if they raise the same or more revenue while reducing the bias against work. Thus, use taxes on activities that follow (are complements of) leisure would reduce the attractiveness of leisure compared to work. ${ }^{41}$ Applied to the example of excessive redistributive tort liability, the argument is that its desirability is exceptional because the liability is a consequence of its construction as a burden of leisure. Thus, the Shavell side would concede the desirability of this redistributional rule, but maintain that redistributional rules are an exception. The exception would be justified only in rules that apply to "strong complements [of,] or substitutes for leisure." 42 The premise for this claim that the desirability of the redistributive rule is exceptional is its equivalence with a use tax, but we saw above that it is unlike a use tax. The redistributive rule of this example is not exceptional, because it does not distort demand for the activity the way that a use tax would, because the rule does not require the revelation of skill, and because the rule redistributes more than the cost in dollars it imposes on the rich.

\section{Avoiding General Distortions}

The redistributive rules are not exceptional because they do not distort demand for the activity like a use tax would. A use tax would be imposed on every skier or every yachtsman. A use tax would be desirable only in exceptional cases because use taxes impose a large burden on the activity. Use taxes reduce the quantity of the activity by making it more expensive, and the reduction is undesirable because it reduces welfare. Take the example of the $\$ 10$ use tax on the $\$ 30$ skiing ticket. Every skier who chooses not to pay the $\$ 40$ price but would have gone skiing if tickets were at $\$ 30$, has lost enjoyment. Redistributive rules that operate by imposing rare large liability, however, are very different from a use tax that raises that same funds. Bankruptcy law grants every insolvent debtor the right to a fresh start. Since the large liability would render every poor skier insolvent, they would utilize their bankruptcy law right to discharge the liability. The consequence is that poor skiers would not be influenced by the redistributive rule. This is a general, rather than an exceptional result. Redistributive rules that operate

41. Taxes on "commodities" (and activities) complementary to leisure and subsidies on those complementary to work will improve welfare by reducing the incentive to avoid work. See generally C.C. Yang \& Hans Haller, Directions of Commodity Tax Reform in the Presence of a Given Non-Linear Income Tax Schedule, 26 CANAD. J. ECON. 469 (1993).

42. Kaplow \& Shavell, Redistributing, supra note 2, at 680. 
by imposing rare large liability will never influence the incentives of the poor because the poor can discharge the liability. ${ }^{43}$

\section{Getting Directly to Skill}

Redistributive rules may operate where skill is revealed. Again, we must compare to the exceptional nature of use taxes in a regime of optimal income tax. The optimal income tax is optimal only if income, rather than productive capacity (called here "skill") is the observable characteristic of individuals. ${ }^{44}$ If skill were observable, any tax scheme with no distortions would be possible, including complete redistribution. Hypothesize two taxpayers, one with the skill to produce up to $\$ 200$ of product and one with the skill to produce up to $\$ 50$. With skill being observable, simply impose a lump-sum $\$ 75$ tax on the first, and give the proceeds to the second. This would not distort incentives for work because both taxpayers would receive the full benefit of additional income. The skilled one, knowing that reducing work does not reduce the tax liability, will not work less.

Proposing such a scheme when skill is not observable may induce the first to only produce $\$ 50$ to avoid the tax, and devote the extra time to play and other leisure activities. An optimal income tax is the best theoretical alternative, as it is designed to induce the least possible incentive to avoid work. In exceptional cases, use or excise taxes can improve upon the optimal income tax by circumventing the impossibility of observing skill. Skill remains not visible, but the tax reaches it because skill is revealed in the circumstances that trigger the tax, so that the skilled choose to pay the tax and the unskilled do not. This is an improvement over raising the same

43. I must rush to say that this does not argue for overall excessive tort penalties. One might be led to so believe by noting that bankruptcy always protects the poor from liability. Overall excessive tort liability would cancel the source of the desirability of the biased rule of the example. The bias was desirable because it cancelled the income tax system's disincentive for work. If all activities of the rich carry the same burden, then the redistribution would not only have the same incentive effects as the tax and the rich would take wasteful care. The double distortion returns.

44. See, e.g., Joseph E. Stiglitz, Pareto Efficient and Optimal Taxation and the New New Welfare Economics, in 2 HANDBOOK OF PUBLIC ECONOMICs 991, 992 (Alan J. Auerbach \& Martin Feldstein eds., 1987) ("It is this limitation on the information of the government which results in taxation being distortionary, and which gives rise to the trade-off between equity and efficiency."). The optimal tax research starts with Mirlees, who received the 1996 Nobel memorial prize in economics. See James Mirlees, An Exploration in the Theory of Optimum Income Taxation, 38 REv. ECON. STuD. 175 (1971). The Nobel press release and information is available on line at www.nobel.se (last visited March 13, 2002). 
revenue with an income tax, since no work incentives are distorted. Such a use tax that produces revelation of skill would be considered exceptional, if not impossible, because no such settings appear to be recognized in the optimal tax literature ${ }^{45}$ The desirability of the redistributive rule, however, does not rest on its ability to induce a revelation of skill. Rather, its desirability exists despite its inability to reveal skill. The general protection the bankruptcy gives to all the poor mans that all the individuals with low skill do choose the activity without suffering the penalty, i.e., without paying the substitute of the use tax. Thus, the desirability of the redistributive rule, rather than being an exceptional phenomenon of revelation of skill, is the norm, because redistribution by large rare liability does not burden those who have little skill. ${ }^{46}$

An example in the line of the signaling literature can be hypothesized to show how a redistributional rule would avoid distortions by operating upon the revelation of skill. A distortive redistributional rule is a general subsidy, that is available in the form of a welfare check payment to everyone who makes less than some income. Such a rule would deter work for some of those who would lose the subsidy. Juxtapose to this a general subsidy, called public housing, which happens to only be used by those of low skill. This would not create a distortion because the skilled would not have a disincentive to work, since they do not use public housing. The background setting would have employers pay a premium to skilled employees, but at the time of hiring, employers cannot determine who is skilled and who is not. While candidates for employment know their skill, they cannot communicate it credibly to employers because candidates of high and low skill can make

45. Although the optimal tax literature does not offer examples of use taxes, excise taxes or commodity taxes that induce the revelation of skill, see supra note 23 , argued that some housing subsidies may induce the revelation of skill if the skilled are induced to not use subsidized housing. A different model does present the possibility that corporations are led to reveal their quality. See Siew Hong Teoh \& Chuan Yang Hwang, Nondisclosure and Adverse Disclosure as Signals of Firm Value, 4 REV. FIN. STUD. 283 (1991) (presenting a model where investors induce firms to send credible signals of their quality although it is not verifiable); see also Nicholas L. Georgakopoulos, Why Should Disclosure Rules Subsidize Informed Traders?, 16 INT'L REv. L. \& ECON. 417, 420 (1996) (explaining the Teoh \& Hwang model).

46. Shavell's side also argues that this exception does not lead to a general rule for biasing rules against the rich because such a policy would discourage activities that allow the rich to be more productive, see Kaplow \& Shavell, Clarifying, supra note 2. To follow the skiing example, if the rich could either ski or walk to their place of business, imposing excessive liability on accidents will make the rich walk, reducing their productivity and aggravating the bias against work of the income tax. This answer does not apply here, because the activity (skiing) is by hypothesis a leisure activity. 
the same statement. Suppose that employees "signal" their quality to employers by declining a verifiable subsidy, such as physical housing. ${ }^{47}$ Only the truly skilled can afford the signal, because the wage premium that employers pay to those who forego public housing is less than the subsidy. ${ }^{48}$ Thus, the non-tax redistribution (public housing in this example) does not reduce the incentives of the skilled to work because the skilled forego the subsidy. Therefore, the biased rule can be preferable to its optimal income tax substitute. ${ }^{49}$

\section{Redistributing Non-Monetary Welfare}

Redistributive rules are also not exceptional when their redistributive consequences are greater than the monetary redistribution they cause. In other words, the poor gain more than the number of dollars that the rule makes the rich pay. In the case of the excessive liability on accidents from a leisure activity, the poor gain not only the actual payments that the liable rich make, but the poor also gain the consequences of the excessive care that the rule imposes on the rich: increased safety, reduced precaution demands, and feasible precaution. The rule makes the activity more hospitable to the

47. Declining a welfare check, by comparison, would not be verifiable. Employers would not be able to determine the truth of statements by candidates for employment that they declined their welfare checks.

48. The candidates of high skill are willing to forego public housing because subsequent wage increases will more than compensate for the loss. To be complete and justify public housing as a measure that increases welfare regardless of distribution, a pure signaling model would have to also show that the same outcome does not materialize without public housing. The example may be expanded to have the employers train employees in the first year of employment but have training be cost-justified only if it were offered to candidates of high skill. Then public housing would be necessary to separate those of high skill, and without public housing no training would be offered (and candidates could not finance they own training because lenders would also not be able to observe skill). While this extension is plausible and necessary for public housing to be necessary for increasing welfare, it is not necessary to justify public housing as a redistributional rule. Even if the same aggregate welfare is available to society without the public housing rule, making the rule pointless for not increasing productivity, public housing is desirable for its redistributional consequences. Public housing in this setting would not involve a reduction in work and would increase redistribution, therefore it would be superior to both the same society without any subsidy and the same society with a general subsidy that would reduce work.

49. For the substitute subsidy to be part of the income tax, it would have to be general, offered to every member of society. Public housing is not a component of the income tax in this example because it would be restricted to specific buildings (this is also what makes it verifiable). The generality of the income tax is discussed further below, at the end of this Part. 
poor, as shown above. ${ }^{50}$ Back to the rule's substitute under optimal income tax: The redistributive payment that would qualify as a substitute for the redistributive rule must include both the amount of the actual monetary redistribution that the rule induces, as well as the benefit to the poor due to the excessive care of the rich. For example, even though rich skiers pay only $\$ 100$ in liability payments to the poor, the poor skiers in aggregate enjoy not only this redistribution of $\$ 100$ of wealth, but also hospitable slopes, reduced and feasible precaution, as well as fewer accidents. ${ }^{51}$ Suppose that all these benefits to the poor are enjoyed by $\$ 50$. The increase in tax that would be equivalent to the redistributive rule is not only the $\$ 100$ of actual redistribution, but the entire $\$ 150$ benefit that the poor receive. Therefore, the increase in taxation that would produce the same outcome would be $\$ 150$, rather that the actual $\$ 100$ cost that the rich skiers bear. The redistribution by means of the tax must raise more funds than the redistribution by means of the non-tax rule. Therefore, the distortion caused by the tax, even if the tax were optimally designed, is likely greater than the distortion caused by the redistributive rule. ${ }^{52}$ The desirability of the

50. See supra text accompanying note 38 .

51. Some of the accidents that do not happen might have been compensated by liability, so that their non-occurrence does not improve, in theory, the position of the would-be victims. Some of the avoided accidents, however, would not have triggered liability for any of a number of reasons, including insufficient care of the injured skier. Those avoided accidents that would have remained uncompensated, do constitute an improvement of the poor skiers' lot.

52. Of course, the Shavell team would promptly respond that the $\$ 100$ figure also understates the cost of the rule to the rich skiers, because it does not include the cost of their additional, wasteful precaution. The rich would expend more in care than the avoided expected accident costs, in the sense that if the rich expended $\$ 50$ in additional care, that avoids less than $\$ 50$ of accidents, but the rich still take this care because it avoids $\$ 50$ of liability. The actual liability would understate the cost of the rule to the rich, due to the increased, wasteful care it induces. Suppose the additional cost of care is $\$ 50$ and the $\$ 100$ liability to the poor is the result of the wastefully reduced risk of accidents. Optimal care would have led to more accidents that would have cost less than $\$ 50$ (since, if the $\$ 50$ care reduced accidents by more than $\$ 50$ it would have been optimal). These accidents would have not have triggered liability, because they would have resulted under optimal care. Therefore, the avoided uncompensated accidents must be added to the benefits that the poor derive from the rule. Thus, the distortionary rule can only be replaced by a tax greater than the aggregate costs to the rich of accidents plus additional care. Yet a different line of thinking would be that the increased care of the rich allows the reduction of the precaution of the poor. If the poor face the same costs of precaution as the rich, the reasonable blind guess of the benefit of reduced precaution should be the same $\$ 50$ that the additional care costs to the rich. To the extent the rich tend to be skilled and the poor less skilled, the poor will not be as efficient of precaution as the rich are in care. Accordingly, the avoided precaution of the poor would 
redistributional rule is not exceptional because even an optimal tax would have to be increased by more than the cost of the redistributive rule to the rich. Three examples of substantive rules that redistribute more welfare than money show that they are not exceptionally rare.

Starting with the more controversial example, consider first the availability of legal abortions and the effect of the availability on teenagers' educational opportunities. ${ }^{53}$ Suppose that teenagers of high skill expect large returns from further education, while teenagers of low skill do not, and the delivery of a baby increases dramatically the cost of more education by reducing the teenage parent's available time and, by occasional ear infections, imposing random disruptions of potentially high cost such as missed exams. Consider first a prohibition on abortions. Teenagers' incentives differ depending on their skill. Teenagers of high skill perceive a pregnancy as more undesirable, because the reduction in their educational capacity that it would bring would carry a great cost; being skilled and educated would lead to significantly greater wages than being skilled and not educated. Accordingly, teenagers of high skill devote much care to avoid pregnancies if abortions are not available. Unwanted pregnancies do occur, but due to the increased care of skilled teenagers, they occur

benefit the poor more than the increased care of the rich burdens the rich. Thus, the avoided precaution may more than cancel the increased care.

53. The significant rationality of pregnancy and abortion choices is manifest in the empirical evidence. Evidence supports the hypothesis of the text that the availability of abortion increases the opportunities for schooling in minorities (read "in the disadvantaged" according to the main text) and little effect in the majority (read "those having large wage gains from education" according to the hypothesis of the text). See generally Joshua D. Angrist \& William N. Evans, Schooling and Labor Market Consequences of the 1970 State Abortion Reforms, NBER Working Paper W5406, available at www.ssm.com (last visited on April 8, 2002), in 18 RESEARCH IN LABOR ECONOMICS 75 (S. Polachek ed., 1999). Similar results are reported in Adam Ashcraft, Identifying the Consequences of Teenage Childbearing, available at www.ssrn.com (last visited April 8, 2002). The choice to not have a potentially desirable (in-wedlock) pregnancy in the face of increased difficulty of obtaining an abortion is documented, along with a thorough review of the literature, by Thomas Kane \& Douglas Steiger, Teen Motherhood and Abortion Access, 111 Q.J. ECON. 467 (1996). The rational choice to travel to states with liberal abortion laws before the universal legalization, is used to determine the benefit due to the availability of abortion. See generally Timothy A. Deyak \& V. Kerry Smith, The Economic Value of Statute Reform: The Case of Liberalized Abortion, 84 J. POL. ECON. 83 (1976). Deborah Haas-Wilson reports evidence that income increases the demand for abortions, consistently with the hypothesis of the text. See Deborah Haas-Wilson, The Impact of State Abortion Restrictions on Minors' Demand for Abortions, $31 \mathrm{~J}$. HUMAN RESOURCES 140, 154-55 (1996). 
disproportionately to the less skilled teenagers and reduce disproportionately their future education and income. Consider now the legalization of abortion. Skilled and unskilled teenagers alike can terminate unwanted pregnancies, eliminating the hazard to education and increased earnings. This benefits both groups, but most of the gain accrues to unskilled teenagers as a group, because the skilled teenagers would avoid most unwanted pregnancies if abortion were prohibited. Legalized abortion has a redistributive effect, increasing the earning capacity of unskilled teenagers. A tax policy that would replicate this redistributive effect would impose an income tax and use the proceeds to help teenagers avoid unwanted pregnancies and to mitigate the educational impediments by providing, for example, daycare in high schools and universities. Even if this policy managed to restore all education that would have been missed, it is an inferior alternative, because the incremental increase of the income tax would deter work. If receiving the daycare subsidy depended on being poor, then the tax substitute of the redistributive rule would impose a second distortion. It would deter work, because work may lead to loss of the subsidy.

For the second example, consider the adoption of "bottle laws" 54 that set up a scheme of a refundable deposit at the purchase of drinks in cans, refunded when the can is properly disposed (recycled). Even without the deposit, wealthy neighborhoods would spend to keep the neighborhood clean. The effect of the law is felt mostly on poor neighborhoods 55 which would not devote comparable resources to street cleaning. Therefore, bottle laws have a redistributional effect. Moreover, the bottle laws do not produce an incentive to avoid work. The deposit causes containers not to litter rich and poor areas alike. It neither induces a preference for poverty nor a penalty on wealth. ${ }^{56}$ Compare the deposit to a tax increase and the spending of the proceeds on the cleaning of poor neighborhoods. The tax creates the incentive to avoid wealth in order to avoid the tax and to not clean the neighborhood so as to keep the subsidy. Notice that these are two distortions. Even if the increased cleaning cost the same five cents per

54. For a recent discussion, see Ann E. Carlson, Recycling Norms, 89 CAL. L. Rev. $1231,1266 \& \mathrm{nn} .141-46$ (2001) (discussing the adoption and evolution of beverage container deposit laws).

55. Bottle laws also have a pronounced effect on rural areas. For the purpose of the example this can be ignored. The reduction of litter in rural areas is consistent with this discussion of the effects of the rule.

56. That bottle laws do not penalize wealth is buttressed by the fact that the rich who choose to recycle their cans can obtain the refund. 
cleaned bottle, ${ }^{57}$ and even if it were funded by an optimal income tax, it is less desirable.

The homeownership bias is the result of a web of rules designed to make home acquisitions easy and desirable. ${ }^{58}$ It operates by inducing the residents of homes to take care of their homes and neighborhoods. Home owners have much stronger incentives than renters to maintain their house and to preserve the quality of the neighborhood. ${ }^{59}$ Even without a homeownership bias, wealthy neighborhoods' houses would tend to have an attractive and wellmaintained appearance. The inducement to maintain the house and care for the neighborhood is felt mostly in poor areas where, under the alternative of predominantly rental housing, maintenance would tend to be inferior and neighborhood involvement less. Although the incentives of the homeownership bias benefit every social segment, the least mobile and

57. It is important to hypothesize that bottle laws do not reduce the true cost of cleaning. If bottle laws also reduce the cost of cleaning, then they constitute of an efficiency gain, which would make them desirable independently of their redistributive effect. For the bottle laws to be desirable only for their redistributive effect, the alternative cleaning costs, funded by an income tax, must be hypothesized to be the same five cents per can that induces the removal of can litter by persons other than the drinker under the bottle laws. Bottle laws can be argued to distort the choice of beverage away from canned drinks and in favor of drinks in cartons. An income tax would remove that distortion. The distortion is small because it is restricted to the drinkers who will not recycle their cans.

58. The tax measures that produce a bias in favor of home ownership are the nontaxation of imputed rent and the mortgage deduction, I.R.C. $\S 25$ (West 2000). Non-tax rules that create biases in favor of home ownership range from the facilitation of home mortgage lending and trading to the exemption of residences from foreclosures and bankruptcy liquidations. See Wells M. Engledow, Cleaning up the Pigsty: Approaching a Consensus on Exemption Laws, 74 AM. BANKR. L.J. 275 (2000) (describing state exemptions and analyzing reform proposals); William E. Nelson \& Norman R. Williams, Suburbanization and Market Failure: An Analysis of Government Policies Promoting Suburban Growth and Ethnic Assimilation, 27 FORDHAM URB. L.J. 197, 228-29 (1999) (discussing the federal facilitation of home financing). Moreover, the bias in favor of homeownership is not a tax rule. The bias in favor of home ownership are substantive, because they change conduct from renting to owning.

59. The incentives of ownership and their erosion are discussed in J.V. Henderson \& Y. M. Ioannides, A Model of Housing Tenure Choice, 73 AMER. ECON. REV. 98 (1983); Thomas J. Miceli \& C.F. Sirmans, Reverse Mortgages and Borrower Maintenance Risk, 22 J. AM. R.E. \& URB. ECON. AssoC. 433 (1994); see also John Harding et al., Deficiency Judgments and Borrower Maintenance: Theory and Evidence, 9 J. HousNG ECON. 267 (2000) (finding that maintenance depends on risk of deficiency judgment by mortgagee against owner); John Harding, Do Owners Take Better Care of Their Housing than Renters?, 28 REAL EsT. ECON. 663 (2000) (finding no evidence that the possibility of resale to a buyer who does not observe past maintenance leads to reduced maintenance, but finding that the sharing the loss with the mortgagee does lead to marginally reduced maintenance by the owner). 
poorest home owners reap a disproportional share of the benefit. Therefore, the homeownership bias has a redistributional consequence. Moreover, the homeownership bias does not induce a distortion to avoid wealth or to prefer leisure. 60 The bias operates on the wealthy and the poor alike. It neither induces a preference for poverty nor a penalty on wealth. Compare the homeownership bias with a tax rule that would (1) treat renting on an equal footing with home ownership and (2) an optimal tax increase that is used to enhance poor neighborhoods. Of the two, only the tax rule creates, first, an incentive to avoid wealth due to the income tax, and, second, an incentive to avoid work in order to receive the subsidy. Again the two distortions burden the optimal income tax substitute.

In all three examples, the source of the desirability of the redistributive rule compared to an optimal tax is that the rules confer a redistributional benefit that is not monetary. The superiority of the redistributive rule is that it produces gains for the poor without imposing monetary costs. The nonmonetary gain means that the redistribution need not be financed by higher income taxes that would deter work. The rules are desirable for their redistributive effect even if tax could fund a program replicating the rules' direct contribution to welfare, preventing loss of education from unwanted pregnancies, cleaning streets to the same level as bottle laws, maintaining and upgrading neighborhoods to the same degree as homeownership. Moreover, if the substitutes contain a targeted subsidy, as all three realistically would, we observe a reversal of the double distortion argument. The double distortion burdens the income tax substitute rather than the redistributive rule.

In sum, the above analysis illustrated the limitations of the thesis that redistribution by an optimal tax is preferred to redistribution by a suboptimal rule. Redistribution by non-tax rules can easily be superior to redistribution by actual, suboptimal taxation. Redistribution by non-tax rules can also be superior to an optimal tax if the rules deter leisure, do not impose a general distortion, apply on revealed skill, or effectuate a non-monetary redistribution of welfare. The next section argues that taxes, by definition, cannot redistribute non-monetary welfare.

60. This would not be true of a rule that would subsidize homeownership conditional on low wealth. Such a rule would create a bias against wealth, because acquiring wealth would cause the loss of the subsidy. By contrast, the general homeownership bias does not change with wealth. 


\section{Separating Tax and Substance}

As the line separating tax from non-tax rules is an artificial and formalistic one, the statement that redistribution should only be provided by an optimal tax system is also vacuous. The tax system is not defined by the proponents of this position. ${ }^{61} \mathrm{In}$ an attempt to determine what constitutes a tax rule, a thought exercise can convert the entire legal system into tax rules. Instead of the law of contracts imposing penalties for breach, posit a tax rule imposing a tax for breaches of contracts and a subsidy to victims of breach. Instead of a tort system imposing liability on injurers, posit a tax system imposing a tax on injurers and granting a subsidy to those harmed. A sufficiently elaborate tax scheme can reproduce the incentives of substantive rules. This cannot be the essential role of tax rules. The incentives that substantive law provides would not be true taxes, even if they were provided by the tax system. The distinguishing feature of rules that provide such incentives is that they do not raise revenue for the government. Instead, substantive rules create incentives by causing potential movements of funds between parties conditional on events or conduct. For example, a rule deterring breaches of contracts, whether written in the Internal Revenue Code or not, produces an incentive not to breach so as to avoid the transfer of compensation to the counterparty. This movement of funds also produces an incentive to avoid the payment and to receive the subsidy, but this consequence is not general, burdening all the rich and benefiting all the poor. Redistribution by non-tax rules, however, includes the redistribution of welfare beyond the redistribution of any payment. Redistributive tax rules only redistribute funds directly or indirectly by funding the provision of services.

61. See Kaplow \& Shavell, Redistributing, supra note 2, at $667 \mathrm{n} .1$ ("For purposes of this article, the term "legal rules" refers to rules other than those that define the income tax and welfare system."). The income tax and the welfare system are not defined. Despite spending much attention to the definition of income, no definition of tax rules is given in Louis Kaplow, Human Capital Under an Ideal Income Tax, 80 VA. L. REV. 1477 (1994). That tax policy occasionally deviates from simply financing the government and tries to influence incentives in ways similar to those of substantive law makes the distinction all the more important. One of the countless examples of such taxes is that on "greenmail," which is the buyout at a premium of hostile shareholders' shares in order to induce them not to seek control of the corporation. See I.R.C. $\S 5881$ (West 2000) (taxing greenmail at 50\%); see, e.g., Nicholas L. Georgakopoulos, Corporate Defense Law for Dispersed Ownership, 30 HoFsTRA L REV. 11, 30-32 (2001) (discussing greenmail). 
Thus, tax rules seem identified by three features: observability, generality, and monetization. Observability captures the notion that taxes do not attempt to identify not readily observable characteristics. Rather, taxes respond to readily quantifiable measures such as income, price, or consumption. Generality means that taxes apply to every individual or to every individual with the observable characteristic. Taxes are general both as burdens and as subsidies. As burdens, taxes fall identically on every individual or at least on every individual of the same observable characteristic, be it income or consumption. The generality of the redistribution has the same shape of the generality of the imposition of taxes. Subsidies and services are general, in the sense that they are available to either every member of society or to every poor member. For example, the demogrant would be a subsidy available to every member, and public schooling or national defense are services offered to every member. Finally, monetization indicates that the direct consequence of taxes is the movement of funds, rather than the imposition of conduct. Taxes raise money and use it to fund subsidies or services. Putting all these elements together, it appears that tax rules are the rules which impose general monetary charges and fund general benefits, where both the charges and the benefits depend on readily observable characteristics of members of society.

Redistributive non-tax rules may redistribute non-monetary welfare. This shows the weakness of the preference for redistribution by means of the tax system. The Shavell side only analyzes redistribution of funds, not welfare. Unsurprisingly, when we realize that rules can redistribute more than funds, the tax system is inapplicable. Rules that restore educational opportunity or induce a cleaning of the inner city are the realm of substantive law.

Tax rules also do not dwell on qualitative differences such as levels of care or the adequacy of consideration, preferring instead universal application in degrees that vary according to some readily ascertained attribute, such as income or consumption. The borders of this definition of the tax system, reminds of what limited the capacity of the optimal tax. The optimal tax can be improved by a system that observes skill or other attributes of productive capacity. Tax law does not dwell that deep. It should come as no surprise that rules that redistribute without distorting incentives take into account details beyond dollar income and, therefore, are not tax rules. Definitions do not prove, but they do exclude. Rules that provide redistribution of non-monetary welfare and rules that depend on other attributes, including schemes to induce the revelation of skill, are not tax rules. All rules should be designed optimally, but it seems that according to 
this definition, rules that provide much redistribution with little distortion of the incentives for work are not tax rules.

\section{POTENTIAL SOLUTIONS: REDISTRIBUTIVE INCENTIVES}

Statisticians can attempt to measure the effect of redistribution on growth, ${ }^{62}$ optimal tax theory can propose universal subsidies and diminishing marginal tax rates, ${ }^{63}$ and others can explore whether the optimal redistribution scheme would exceed subjective preferences for it, ${ }^{64}$ but

62. Such estimates vary widely. Very large estimates of the loss in productivity are made by Martin Feldstein, How Big Should Government Be?, supra note 25, and are reported by Robert W. McGee, Some Tax Advice for Latvia and Similarly Situated Emerging Economies, 13 INT'L TAX \& BUS. Law 223, at notes 64-68 and accompanying text (1996) (reporting growth reduction of $1.1 \%$ annually due to the distortive effects of taxation and an annual loss of $33 \%$ of revenue). A study finding that tax reductions increase growth was questioned. See Reinhard B. Koester \& Roger C. Kormendi, Taxation, Aggregate Activity and Economic Growth: Cross-Country Evidence on Some Supply-Side Hypotheses, 27 EcoN. INQUIRY 367 (1989) (finding that tax cuts increased productivity); cf. Charles Garrison \& Feng-Yao Lee, Taxation, Aggregate Activity and Economic Growth: Further Cross-Country Evidence on Some Supply-Side Hypotheses, 30 ECON. INQUIRY 172 (1992) (questioning the conclusions of Koester \& Kormendi). The problem with estimates of incentive effects is that in the long run the return on capital and the cost of goods should adjust to the demand for saving and consumption that the tax structure induces and cancel out the bias of the tax system. A more immediate problem with the evidence is that evidence of increased productivity may simply imply that when redistribution is too little, increasing it also increases productivity because of the productivity-increasing side-effects of redistribution such as better education, lower crime, and improved transportation. The distortive effect of taxes must be estimated separately from the productivity gains due to redistribution. Establishing the optimal degree of redistribution is a separate question than establishing the optimal means to provide it. Cf. James R. Repetti, Democracy, Taxes, and Wealth, 76 N.Y.U. L. Rev. 825 (2001) (interpreting this evidence as indicating that more redistribution is beneficial). Economists find redistribution increases growth. See, e.g., Woojin Lee \& John E. Roemer, Income Distribution, Redistributive Politics, and Economic Growth, 3 J. Econ. GrowTH 217, 233 (1998); Gilles Saint Paul \& Thierry Verdier, Inequality, Redistribution and Growth: A Challenge to the Conventional Political Economy Approach, 40 EUR. ECON. REv. 719, 725-26 (1996); William Easterly \& Sergio Rebelo, Fiscal Policy and Economic Growth: An Empirical Investigation, 32 J. MONETARY ECON. 417, 419, 421-22 (1993) (noting that the effect of tax changes was unclear).

63. Optimal tax theory proposes a lump-sum payment to everyone, which is called a demogrant. See Zelenak \& Moreland, supra note 29, at $52-57$ (considering demogrants unrealistic).

64. See Kaplow \& Shavell, Fairness Versus Welfare, supra note 2; Kaplow \& Shavell, Notions of Fairness Versus the Pareto Principle: On the Role of Logical Consistency, supra note 2 . 
current redistribution seems clearly inadequate. Nevertheless, an incremental increase in redistribution is seen as too costly in terms of the reduction that increased taxes would impose on growth. This is the essential puzzle of redistributive concerns, but Economic Analysis of law can break the deadlock. Economic analysis of law has tools that can show the way out of the confounding quandary of insufficient and yet unaffordable redistribution. Two methods are proposed. The first deploys one of the cornerstones of economic analysis, Coasean irrelevance. Rules should be designed so as to reduce transaction costs and rights should be allocated so that the rich must buy them from the poor. If transaction costs are low enough, the trades will allocate the rights optimally while providing redistribution. The second looks at proposals from the Law-and-Economics academy that redistribute welfare directly, without distorting incentives, so as to facilitate the production of more such rules.

Ronald Coase's work has been interpreted as saying that in a perfect world, legal rules would be irrelevant (and continuing to say that in the real world they are not because of transaction costs). ${ }^{65}$ The first of this double proposition of Coase can be called Coase's irrelevance theorem. It states that in a perfect world, people would agree to circumvent disadvantageous assignments of rights and obligations. If the law entitled, for example, farmers to fences, ranchers who wanted their cattle to graze unimpeded by fences would buy that right if fencing were more expensive than grazing elsewhere. If the law prohibited fences, farmers who wanted to keep cattle off their land would buy that right from the ranchers if the injury by trampling cattle cost more than moving the cattle elsewhere. Or, if factories were entitled to pollute, downstream farmers would buy filters for upstream polluters if the injury by the pollution was greater than the cost of the filter. If polluting were prohibited, upstream polluters would buy the tolerance of downstream farmers if the filter cost more than the pollution's injury. In the world of Coasean irrelevance, the law does not determine outcomes. People, the market, rearrange rights and obligations to override their wasteful suboptimal allocations. ${ }^{66}$

The Coase irrelevance theorem has had a defining influence on economic analysis of law. It renders deregulation the "by default" desired

65. Ronald Coase, The Problem of Social Cost, 3 J.L \& ECoN. 1 (1960).

66. For a very readable introduction to Coasean analysis, see DAVID D. FRIEDMAN, LAW'S ORDER: WHAT ECONOMICS HAS TO DO WITH LAW AND WHY IT MATTERS 36-46 (2000). See also Nicholas L. Georgakopoulos, The Coasean Irrelevance 'Theorem', CALI lesson, 2002, which is accessible at my website, www.nicholasgeorgakopoulos.org, under the teaching link, forthcoming at www.cali.org. 
system of regulation. Advocates of regulation bear the burden of proof that the parties will not circumvent the rules or that this circumvention is undesirable. But if redistribution is the goal when we look at the agreements effectuated to circumvent rules, the presumption that Coasean irrelevance creates is reversed. While for every other regulatory motive, Coasean irrelevance suggests legal design is pointless, Coasean irrelevance suggests that redistribution can be achieved with no loss of efficiency by inducing agreements that circumvent sub-optimal assignments of rights. To redistribute, for example, from the ranchers to the farmers, simply assign the right of fencing to farmers. When ranchers will come and buy grazing rights from the farmers, the desired redistribution will take place. Thus, while Coasean irrelevance makes every argument about substantive regulation much harder, it shows that the allocation of rights can further redistributional goals without causing substantive distortion. The allocation of rights that furthers redistribution does not reduce welfare, because the parties will bargain around the suboptimal allocation. While Coasean irrelevance casts doubt on the usefulness of every substantive rule, it also creates a presumption that reallocation of rights to promote redistribution will be equally irrelevant for substance and suboptimal allocations of rights will be circumvented. If the suboptimal allocation is such that the circumvention promotes redistributive goals-the rich buying rights from the poor-Coasean irrelevance means that no efficiency is lost.

When we realize that the same Coasean irrelevance that hampers rulemaking, encourages distributional reallocations, we should realize that the discussion in Section IV about the desirability of distributional motives in rules, was missing the proverbial boat. Distributional motives are by default irrelevant. Rules motivated by distributional concerns do not produce inefficiencies because the parties will "contract around" the rules or adjust their conduct, either canceling the redistribution or imposing waste. In the case of the redistributional policy of public schooling, the canceling behavior is the "white flight" and the drop of the prices of homes in poor school districts. ${ }^{67}$ The waste is the duplicative private funding of independent schools to address the educational needs of that part of the population that both cares about education and can afford the independent schools.

Coasean irrelevance changes the mode of normative thought about redistribution. Instead of conceiving of redistributive rules designed to direct

67. David M. Cutler et. al., The Rise and Decline of the American Ghetto, 107 J. PoL. ECON. 455 (1999) (finding that whites pay more to live in white neighborhoods). 
payments, Coasean irrelevance suggests that redistribution would be achieved by rules assigning rights, designing markets, and otherwise facilitating Coasean trades, i.e., purchases of rights. Since this is a direct consequence of Coasean irrelevance, I call this type of redistribution which is achieved by means of Coasean bargains, Coasean redistribution. Compared to taxation's forced taking of funds from the taxpayer, facilitating trade is a subtler task for legal design. Nevertheless it is a task very familiar to economic analysis scholars, one that has reached front-page prominence with the success of the market for trading rights to sulfur dioxide emissions. ${ }^{68}$ Trading regimes should be designed even more easily for redistributive purposes than they were designed for environmental purposes. Some applications exist and others are easy to envision.

The most familiar Coasean redistributive bargain is charitable giving. 69 Consider also less overt redistributive bargains, such as the auction for surrenders of seats in overbooked airplanes. Those for whom the reward is worth the delay, give up their seats and receive the reward. Those are the passengers who value speedy arrival the least, an attribute that is likely to correlate, albeit imperfectly, with wealth. This is a bargain struck by the airline as an intermediary of the passengers who value speedy arrival the most, with the recipients of the redistributive payment. A different version of a Coasean redistributive bargain is struck by an intermediary of the beneficiaries, with the sources of the redistribution.

The government grants many rights that provide valuable incentives for production but operate in a counter-redistributive manner. Patents, copyrights and trademarks are at the source of massive accumulations of wealth. They can all require the payment of a fee, depending on their value, the proceeds of which can be used to further redistribution. ${ }^{70}$ The

68. See infra notes 73-74 and accompanying text.

69. For a discussion of the complexities surrounding charity and altruism, see Eric A. Posner, Law and Society \& Law and Economics: Common Ground, Irreconcilable Differences, New Directions: Altruism, Status, and Trust in the Law of Gifts and Gratuitous Promises, 1997 WIS. L. REv. 567.

70. Collecting from successful patents and subsidizing a needed service is not only a solution to a general social desire for equity, but it could also be structured to ameliorate the problem of all the patents the owners of which visualized no commercial use at the time of their filing, such as the gene sequence patents.

Numerous scholars have decried the rush to patent gene sequences of unknown usefulness. See, e.g., Daniel L. McKay, Patent Law and Human Genome Research at the Crossroads: The Need for Congressional Action, 10 SANTA ClARA COMPUTER \& High TECH. L.J. 465, 466 (1994); Byron V. Olsen, The Biotechnology Balancing Act: Patents for Gene Fragments, and Licensing the "Useful Arts," 7 ALB. L.J. SCI. \& TECH. 295, 307-308 (1997) 
intellectual property protection granted to drug companies should require payment of a fee that would be based on the actual sales of the patented item (usually drug) during a first period of its commercial use. The proceeds of this fee should be collected in a fund that would finance the underfunded service, be it vaccinations, medical care for the poor, or basic research at universities. The fund, of course, should be separated from general government revenues, as so many similar plans are. A related regime is already in effect on vaccines, imposing a fee for the benefit of the victims of their side-effects, imposed by the National Childhood Vaccine Injury Act on $1986 .{ }^{71}$ Funds are collected by imposing a fee on the sale of vaccines and the proceeds are used to compensate children who develop harmful side effects. The redistribution is from the lucky, the children who do not develop side effects but have to pay a higher price for the vaccine, to the unlucky children who develop the harmful side effects.

The structure of such fees is not complex. The fee would be small compared to projected sales. Moreover the fee would only be necessary for. those patents that are actually commercially used, and would be due after they are commercially used for a long enough period of time. Some patents may never be used commercially, and their holder may never owe the fee. Others may reach commercial use immediately or several years after the granting of the patent. A reasonable period for the calculation of sales could be two years and the baseline percentage for patents that reach immediate commercial application may be $10 \%$ of those two years' sales. Patents that reach commercial application later in the patent-protected period should pay a smaller fraction, to compensate for the shorter remaining time for their exploitation. The continued applicability of the parent protection should, of course, depend on the payment of this fee, and incentives should be designed so that its monitoring is left to the competitors who want to use the patent.

It is important to note that this proposal applies to every area of intellectual property protection that the government grants. The copyright protection given to movies and music can include such a fee that would

(discussing the "genetic goldrush"); Arti Rai, Addressing the Patent Gold Rush: The Role of Deference to PTO Patent Denials, 2 WASH. U. J.L. \& POL'Y 199 (2000).

71. National Childhood Vaccine Injury Act of 1986,42 U.S.C.A. $\S \S 300$ aa-1 to -34 (West 2001). The arrangement also precludes tort claims against the vaccine manufacturers. See generally Andrew R. Klein, A Legislative Alternative to "No Cause" Liability in Blood Products Litigation, 12 YALE J. ReG'N 107, 123 et seq. (1995); Andrew R. Klein, Beyond DES: Rejecting The Application of Market Share Liability in Blood Products Litigation, 68 TUlane L. Rev. 883, 931 et seq. (1994); Andrew R. Klein, Rethinking Medical Monitoring, 64 BROOK. L. REv. 1, 29 (1998). 
subsidize neighborhood theaters or acting schools and regional orchestras and music schools. The trademark protection could also include such a fee that could subsidize architecture or design study. The copyright protection of computer code can be used to subsidize computers for poor school districts. The administration of the disbursement system must be made as automatic as possible, perhaps by using matching funding that gives to the organization a fraction of the proceeds it receives from the public. Thus schools, theaters and museums would receive funds depending on their tuition income, ticket sales, or donations. Institutions that do not have such income, as public schools, would receive matching funds in their expenses, such as teacher salaries or technology purchases.

Such fees would distort incentives to work, but probably less than an incremental increase of the current income tax. The class that might be influenced are those who develop works protected by intellectual property rights. First, the fees only burden the most valuable of those rights, while some redistributional benefits flow to others in the same class. That top filmmakers are charged a fee does not influence the incentives to become a filmmaker if the fee is used to reduce the cost of film school. Moreover, those who obtain intellectual property rights will pass part of the cost of the fee to the consumers. Nevertheless, when such an involuntary redistributive scheme does reduce the incentive for work, it must also be compared to the same redistribution by means of an optimal income tax. The proposed measure may be superior because the redistributive burden is not general but falls on filmmakers alone, or other recipients of intellectual property, and because the acquisition of intellectual property rights may be a revelation of skill. This would likely make such redistributive schemes superior to their substitute even under an optimal income tax. ${ }^{72}$

72. The likely superiority of the proposal for a fee and targeted subsidies around intellectual property rights, is due to the potential revelation of skill in the acquisition of intellectual property rights and due to their lack of generality. The avoidance of a distortion because of the revelation of skill is not be completely true, because the fee would still induce the skilled to work less in the creation of the protected work. For example, the fee would induce skilled filmmakers to be slightly less perfectionist in shooting their films, since the income from the film is reduced by the amount of the fee. In other ways, however, the fee would not allow the hiding of skill. Talented filmmakers cannot take advantage of their skill without the intellectual property protection.

The concentration of the fee and the subsidy on the activity of the intellectual property suggests that the distortion on the incentives to work that it causes could be smaller than a general distortion induced by an income tax. Thus, although skilled filmmakers have an incentive to work less, the distortion caused by the equivalent income tax could be greater because it would distort the incentives of every taxpayer. The scheme would create an 
The experience with the trading of sulfur dioxide emissions, indicates that firms can manage costs surprisingly well and with continued improvements. When the permits began trading, their price was smaller than expected, because firms had a better handle on pollution than anticipated..$^{73}$ The surprise was due to the lack of appreciation of the impact of profit on corporations, institutions designed to produce profit. Once pollution had a price, every link in the chain of the corporate organization, from chief executives to janitors, recognized the interest to reduce pollution. Unsurprisingly, pollution was reduced in creative and unexpected ways. ${ }^{74}$

This effectiveness is a typical example of the benefits that are not available to an income tax alternative. An heavier income tax on polluting factories would create a wasteful incentive to operate them less. The license trading scheme created the desired incentive, to make them pollute less. The superiority of the license trading regime is due to the fact that the incentives it creates depend not on money but on the production of the targeted good, cleanliness. The surprising effectiveness of corporations in fighting pollution should indicate that a similar surprise may be in store for achieving redistributional goals. Traded rights in the subject of the redistribution would motivate and create incentives to achieve the goal directly, without interposing the distortive effect of a monetary redistribution.

The incentives can be given directly or to intermediary entities. If the goal is to reduce high school dropouts, teen pregnancy, or basic prenatal care, the students who remain in school, not pregnant or the expecting mothers who avoid specified risks and receive medical procedures, would receive stipends. An intermediary, such as the school, the city, or city hospitals, could also be given "licenses to failure", that would operate in ways similar to the licenses to pollute. If the social failures are reduced, the intermediary would receive a refund for, or sell the unnecessary licenses. The licenses would not be needed if student performance exceeds the

undesirable bias in favor of the less skilled engaging in filmmaking in order to receive the subsidy.

73. Daniel Cole has studied the sulfur trading rights emissions. See Dantel. H. Cole, POLLution AND PROPERTY: COMPARING OWNERShIP INSTITUTIONS FOR ENVIRONMENTAL Protection (forthcoming 2002, Cambridge University Press); Daniel H. Cole, Clearing the Air: Four Propositions About Property Rights and Environmental Protection, 10 DUKE ENVT'L L. \& POLICY For. 103, 115 (1999).

74. Kurt Strasser discusses the numerous innovations that reduced pollution. See Kurt A. Strasser, Preventing Pollution, 8 Fordham ENV. L.J. 1, 16-22, passim (1996) (discussing several cases of major corporate innovation in the manufacturing process that dramatically reduced pollution); see also Kurt A. Strasser, Cleaner Technology, Pollution Prevention and Environmental Regulation, 9 FORDHAM ENV. L.J. 1 (1997). 
targets, if teenage pregnancy is less than expected, if prenatal care is better than expected. For example, a standardized test could measure student's performance and all students would receive stipends depending on their performance; schools or cities could get funds depending on average scores or licenses to failing students that they could sell if they are not needed to cover the failing students. The goals must be adjusted for socioeconomic background. ${ }^{75}$ Prenatal care would probably follow a slightly different pattern. Expecting mothers would be given vouchers with entries for the required care, such as negative drug or alcohol tests, and the submission to sonograms or other indicated tests. The vouchers would entitle them to a distribution the size of which would depend on the fulfilled care. As an intermediary, inner-city hospitals could be given licenses to overall newborn health in their area. Although it initially seems more difficult, someone might even be able to devise incentive schemes to address the more evanescent deficiencies with which the Left accuses the capitalist system. Perhaps incentive design could improve self-determination, self-realization, meaningful work, or non-alienated relations. ${ }^{76}$

The experience with emissions trading suggests that such proposals may have very different results than simply the collection of a fee and its use for school improvement or for the provision of preventive medicine. The difference lies in that individuals and intermediary institutions will internalize the goal directly. Institutions would put their effective creativity, monitoring, and cost-reduction apparatus to bear on achieving results. Just as the ranchers will do their best to achieve the goal of reducing the trampling by their cattle, so the intermediary institutions which must buy pollution licenses, non-graduation allowances, or skipped-prevention vouchers will do their best to achieve the goals of reduced pollution, increased graduation rates, the delivery of preventive medicine, or the desired service on which their funding or profitability depends. A realistic implementation could distribute tax-credit vouchers the usefulness of which would depend on the improvement of the chosen statistic-high school test scores, preventive medicine regimes, innovations in basic research and so forth. Entities in regions that experience the improvement of the statistic would receive the benefit of the tax credit. This would increase their incentives to help this

75. An adjustment for socioeconomic background is crucial. Otherwise such licenses can operate in a counter-redistributive way, if poor school districts lose benefits for violating their licenses. To avoid this, licenses should be granted to school districts according to their current tests scores, adjusted for performance shortfalls explained by socioeconomic status, and normalized for aggregate changes in students' performance over the years.

76. A similar hint exists in Schlag, supra note 1 , at 953. 
improvement. Such vouchers would be superior to the income tax alternative because instead of reducing the incentive to work, these vouchers would increase it. The students, schools, hospitals, and expecting mothers are given an incentive to produce more in order to receive a benefit. A subsidy would have created the opposite effect, inducing ineffectiveness in order to preserve the right to receive the subsidy.

Developing redistributive incentive schemes is a task to which law and economics scholars are uniquely able to contribute and have a tradition of producing. ${ }^{77}$ They are uniquely able to contribute because they focus on incentives and how the legal system shapes them. The potential importance of this contribution is massive. An example is visible if we contrast the development of incentive schemes for educational goals suggested above with the currently popular policy alternative, vouchers entitling parents to private school tuition. As the proposed vouchers are only sufficient for subsidized private schools, mostly religious, their effect on incentives would be pernicious. Vouchers for alternative schools do nothing to improve the schools' weakest and presumably easiest to improve students. Moreover, instead of producing an incentive on the weakest students and their family to increase their educational effort, vouchers remove the students and families who do care about education from the educational community of the school, leaving behind the weakest, and least attentive to education, students. Finally, vouchers send to lower-spending schools students who may be able to benefit from the greater spending of public schools. Schemes that would provide educational incentives would avoid all these negative consequences and improve the existing schools.

Three more ubiquitous examples of redistributive policies are legalized abortion, the five-cent beverage container deposit laws and the homeownership bias, all discussed above. ${ }^{78}$ The list of redistributive non-tax rules continues. John Lott shows that the benefits of permits for concealed firearms accrue mostly to the weak. ${ }^{79}$ Ian Ayres and Steven Levitt notice

77. Redistributive rules that have been advanced by members of the Law and Economics academy include the random installation of Lojack remote tracing units in appliances that are at risk of theft, of "blind" political giving, and of the "shall issue" concealed carry licenses. They are discussed briefly below, text accompanying notes 79-82.

78. See supra text accompanying notes 52-60.

79. John R. LOTT, MORE GunS Less CRIME (1998); John R. Lott, Jr. \& David B. Mustard, Crime, Deterrence, and Right-to-Carry Concealed Handguns, 26 J. LEGAL STUD. 1 (1997); John R. Lott, Jr., Does Allowing Law-Abiding Citizens to Carry Concealed Handguns Save Lives?, 31 VAL. U. L. REv. 355, 361 (1997) (discussing the pronounced reduction of crime against women); John R. Lott, Jr. \& William M. Landes, Multiple Victim Public Shootings, Bombings, and Right-to-Carry Concealed Handgun Laws: Contrasting Private 
that installations of Lojack units that help recover stolen cars, reduce car theft. ${ }^{80}$ Expanding on the same theme; they propose subsidized installation of Lojack in property that is the target of crime. This proposal is redistributive to the extent that the rich areas and houses can afford security measures and avoid crime anyway. Moreover, the precaution of the rich would tend to displace property crime to poor neighborhoods. A proposal for anonymous political giving was expressly designed as a redistributive rule, to reduce the political influence of the rich.81 In addition of the redistributive effect of abortion discussed above, as John Donohue and Steven Levitt show, the availability of abortion also reduced crime, ${ }^{82}$ revealing one more redistributional effect. Families with skill, self-control, and education avoid producing less desired and potentially criminal offspring. The availability of abortion lets the lesser families share this benefit. The redistributive effects of some of these rules could be replicated by income taxes. Taxes would reduce incentives to work, while these rules do not. Thus, some of these rules could be considered desirable even if their only consequence were the non-monetary redistribution that they induce.

\section{CONCLUSION}

Redistributing through taxation sacrifices growth. Redistributing through the schemes analyzed in this essay does not. Moreover, general taxes that only raise funds are "dumb" policy tools, providing no desirable incentives compared to the design of redistributive rules, which produce direct incentives for the redistributive goal. Even the ideal of optimal tax theory is optimal insofar as it distorts the least: it induces the least reduction of the incentive to produce and induces the least bias in favor of leisure. Regimes of redistributive Coasean bargains and rules that induce directly the redistributive goal, by contrast, induce "smart" redistribution in the same sense that trading emission licenses induces "smart" environmental protection compared to "command and control" environmental rules. The incentives that redistributive rules produce can go directly to the redistributive goal, such as educating inner city youth, providing preventive

and Public Law Enforcement, available at www.ssm.com (last visited April 12, 2002).

80. Ian Ayres \& Steven D. Levitt, Measuring Positive Externalities from Unobservable Victim Precaution: An Empirical Analysis of Lojack, 113 Q.J. ECON. 43 (1998).

81. Ian Ayres \& Jeremy Bulow, The Donation Booth: Mandating Donor Anonymity to Disrupt the Market for Political Influence, 50 STAN. L. REv. 837 (1998).

82. John J. Donohue III \& Steven D. Levitt, The Impact of Legalized Abortion on Crime, 116 Q.J. ECON. 379 (2001). 
medicine, or increasing basic research. Economic analysis of law can prove invaluable by designing such redistributive incentive schemes. Compared to optimal tax theory, redistribution by non-tax rules is superior because it reaches where optimal taxation cannot. Redistributive rules improve the welfare of the poor: they induce the recycling bottles and maintenance of houses in poor neighborhoods, they make poor students and parents become involved with their schools, they lead at-risk mothers to avoid risks. Redistributive rules grow the pie that taxation, even if optimal, would shrink. 